\title{
₹USGS
}

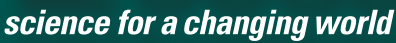

Prepared in cooperation with the Lummi Nation

Estimating Low-Flow Frequency Statistics and Hydrologic Analysis of Selected Streamflow-Gaging Stations, Nooksack River Basin, Northwestern Washington and Canada

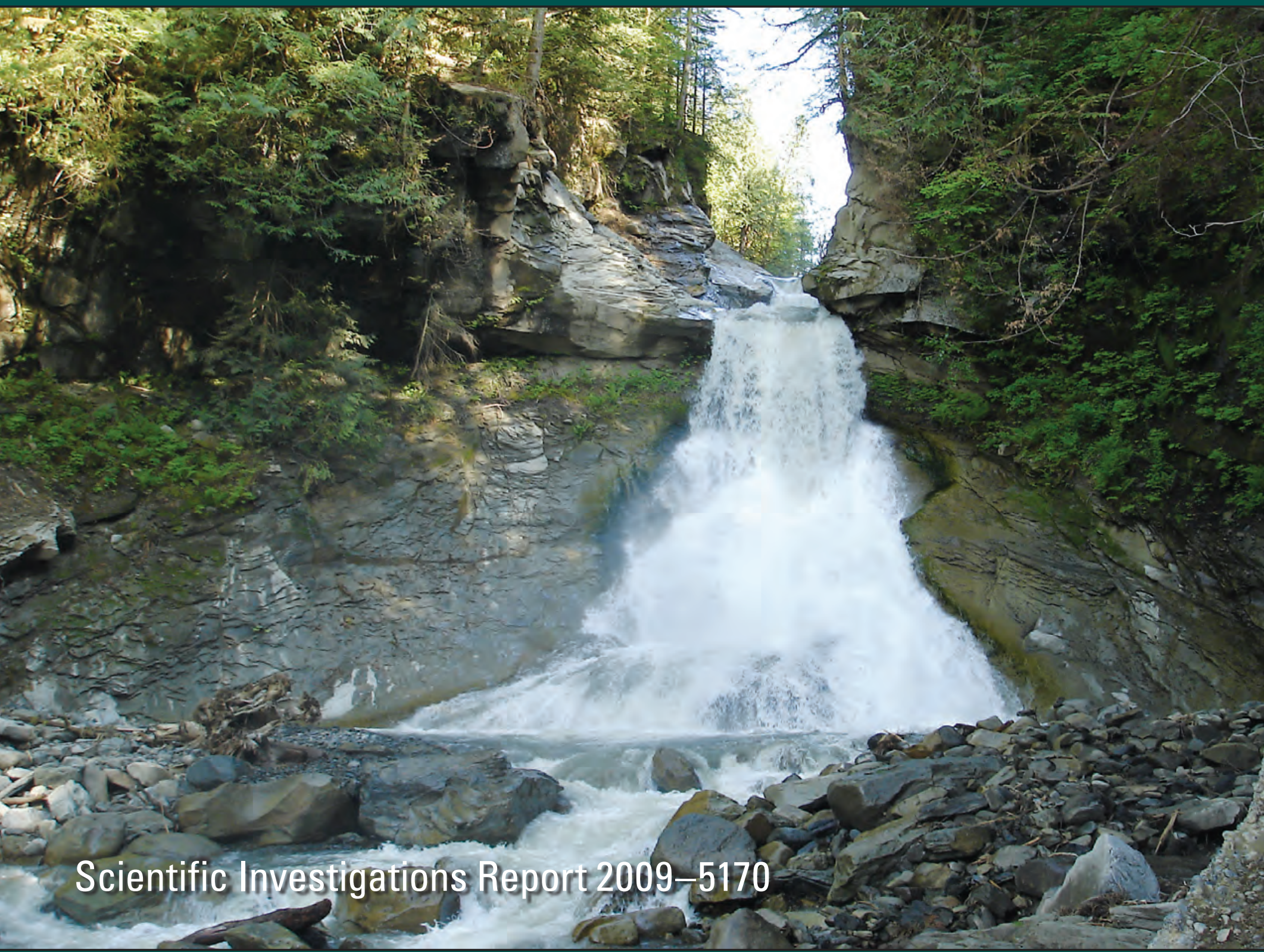


Cover: Photograph of Racehorse Falls near Kendall, Washington. (Photograph taken by Christopher A. Curran, 2009.) 


\section{Estimating Low-Flow Frequency Statistics and Hydrologic Analysis of Selected Streamflow-Gaging Stations, Nooksack River Basin, Northwestern Washington and Canada}

By Christopher A. Curran and Theresa D. Olsen

Prepared in cooperation with the Lummi Nation

Scientific Investigations Report 2009-5170 


\section{U.S. Department of the Interior \\ KEN SALAZAR, Secretary \\ U.S. Geological Survey \\ Suzette M. Kimball, Acting Director}

U.S. Geological Survey, Reston, Virginia: 2009

For more information on the USGS - the Federal source for science about the Earth, its natural and living resources, natural hazards, and the environment, visit http://www.usgs.gov or call 1-888-ASK-USGS

For an overview of USGS information products, including maps, imagery, and publications, visit http://www.usgs.gov/pubprod

To order this and other USGS information products, visit http://store.usgs.gov

Any use of trade, product, or firm names is for descriptive purposes only and does not imply endorsement by the U.S. Government.

Although this report is in the public domain, permission must be secured from the individual copyright owners to reproduce any copyrighted materials contained within this report.

Suggested citation:

Curran, C.A., and Olsen, T.D., 2009, Estimating low-flow frequency statistics and hydrologic analysis of selected streamflow-gaging stations, Nooksack River basin, northwestern Washington and Canada: U.S. Geological Survey Scientific Investigations Report 2009-5170, 44 p. 


\section{Contents}

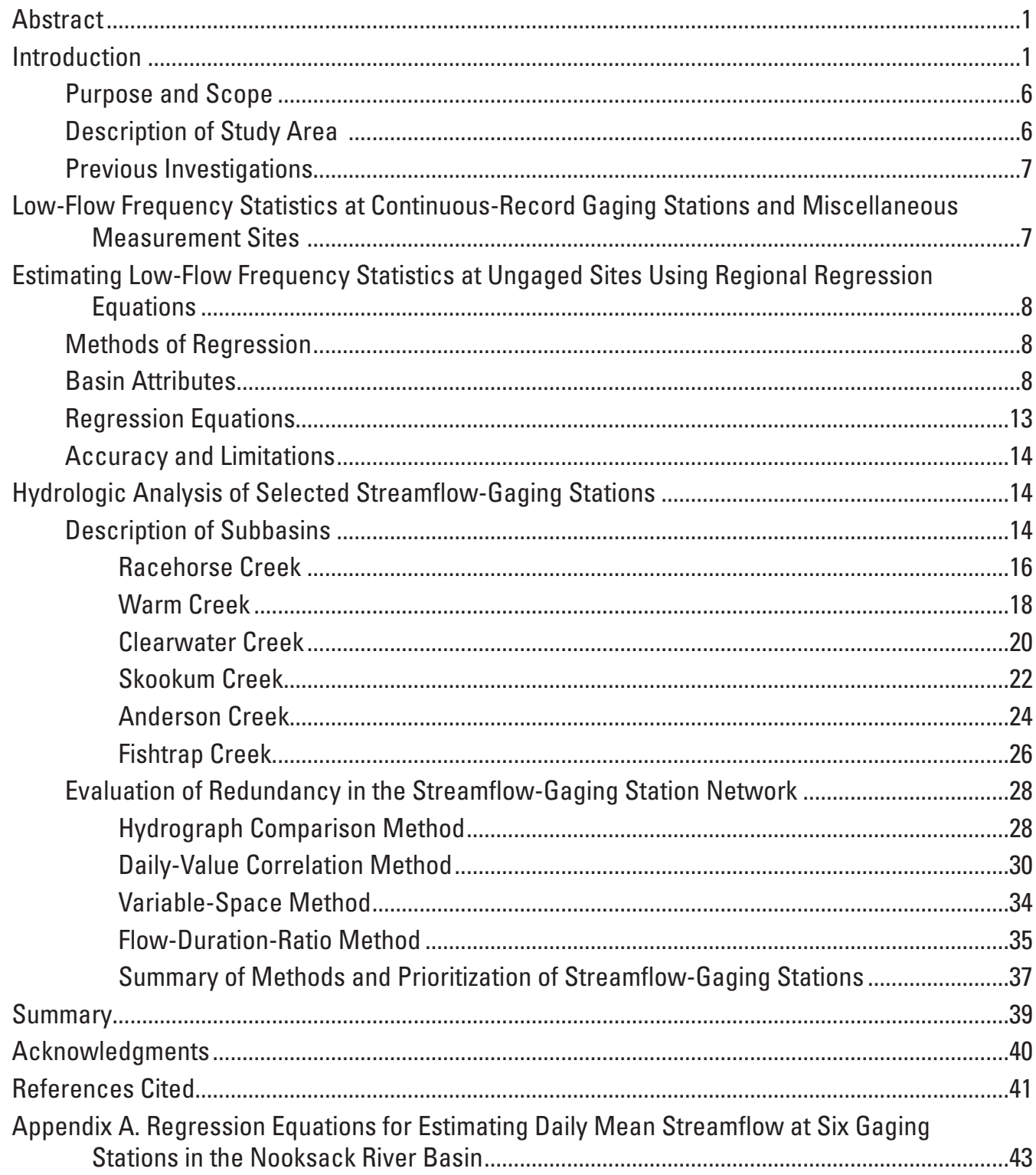




\section{Figures}

Figure 1. Map showing location of the Nooksack River basin and major rivers and population centers in the basin, Washington and Canada

Figure 2. Map showing locations of streamflow-gaging stations and miscellaneous measurement sites in and near the Nooksack River basin, Washington and Canada

Figure 3. Map showing location of streamflow-gaging stations in Racehorse, Warm, Clearwater, Skookum, Anderson, and Fishtrap Creek subbasins that were analyzed for redundancy in the streamflow-gaging station network, Nooksack River basin, Washington and Canada

Figure 4. Satellite image showing oblique view and delineation of the Racehorse Creek subbasin with the January 2009 landslide area, Nooksack River basin, Washington

Figure 5. Photographs showing view looking upstream $(A)$ and downstream $(B)$ from the U.S. Geological Survey streamflow-gaging station on Racehorse Creek at North Fork Road, near Kendall, Washington

Figure 6. Satellite image showing oblique view and delineation of the Warm Creek subbasin, Nooksack River basin, Washington

Figure 7. Photographs showing view looking upstream $(A)$ and downstream $(B)$ from the U.S. Geological Survey streamflow-gaging station on Warm Creek near Welcome, Washington

Figure 8. Satellite image showing oblique view and delineation of the Clearwater Creek subbasin, Nooksack River basin, Washington

Figure 9. Photographs showing view looking upstream $(A)$ and downstream $(B)$ from the U.S. Geological Survey streamflow-gaging station on Clear Water Creek near Welcome, Washington

Figure 10. Satellite image showing oblique view and delineation of the Skookum Creek subbasin, Nooksack River basin, Washington

Figure 11. Photographs showing view looking upstream $(A)$ and downstream $(B)$ from the U.S. Geological Survey streamflow-gaging station on Skookum Creek near Wickersham, Washington

Figure 12. Satellite image showing oblique view and delineation of the Anderson Creek subbasin, Nooksack River basin, Washington

Figure 13. Photographs showing view looking upstream $(A)$ and downstream $(B)$ from the U.S. Geological Survey streamflow-gaging station on Anderson Creek near Goshen, Washington

Figure 14. Satellite image showing oblique view and delineation of the Fishtrap Creek subbasin, Nooksack River basin, Washington

Figure 15. Photographs showing view looking upstream $(A)$ and downstream $(B)$ from the U.S. Geological Survey streamflow-gaging station on Fishtrap Creek near Lynden, Washington

Figure 16. Graph showing daily streamflow runoff at six streamflow-gaging stations in the Racehorse, Warm, Clearwater, Skookum, Anderson, and Fishtrap Creek subbasins, Nooksack River basin, Washington and Canada, water year 2003 


\section{Figures-Continued}

Figure 17. Graph showing fifteen-minute streamflow and average tau $(\tau)$ values during the period of July 11-31 at six gaging stations in the Racehorse, Warm, Clearwater, Skookum, Anderson, and Fishtrap Creek subbasins, Nooksack River basin, Washington and Canada

Figure 18. Scatter plots and correlation coefficients (Pearson's $r$ ) showing relation among the natural logs of daily mean streamflows during the summer, winter, and spring seasons at each of six gaging stations in the Racehorse, Warm, Clearwater, Skookum, Anderson, and Fishtrap Creek subbasins, Nooksack River basin, Washington and Canada

Figure 19. Graph showing drainage area and mean basin elevation for all gaging stations used in the regional regression analysis for estimating low-flow frequency statistics at ungaged sites, Nooksack River basin, Washington and Canada

Figure 20. Graph showing 090/050 ratios for all sites used in the regional regression analysis for estimating low-flow frequency statistics at ungaged sites, Nooksack River basin, Washington and Canada

Figure 21. Graph showing 010/050 ratios for all sites used in the regional regression analysis for estimating low-flow frequency statistics at ungaged sites,

Nooksack River basin, Washington and Canada

\section{Tables}

Table 1. Streamflow-gaging stations and miscellaneous measurement sites in and near the Nooksack River basin, Washington and Canada.....

Table 2. Low-flow frequency statistics for continuous-record gaging stations and miscellaneous measurement sites in and near the Nooksack River basin, Washington and Canada

Table 3. Basin attributes and their source data considered in the regional regression analysis for estimating low-flow frequency statistics at ungaged sites, Nooksack River basin, Washington and Canada

Table 4. Basin attributes for continuous-record gaging stations and miscellaneous measurement sites used in the regional regression analysis for estimating low-flow frequency statistics at ungaged sites, Nooksack River basin, Washington and Canada

Table 5. Regression equations for estimating low-flow frequency statistics at ungaged sites in the Nooksack River basin, Washington and Canada

Table 6. Summary of correlation coefficients (Pearson's $r$ ) showing patterns among the natural logs of daily mean streamflows at six gaging stations in the Racehorse, Warm, Clearwater, Skookum, Anderson, and Fishtrap Creek subbasins during summer, winter, and spring seasons, Nooksack River basin, Washington and Canada

Table 7. Summary of results by method for determining optimal combinations of streamflow-gaging stations to retain in six subbasins, Nooksack River basin, Washington and Canada

Table 8. Prioritized list of streamflow-gaging stations to retain in six subbasins of the Nooksack River basin, Washington and Canada 


\section{Conversion Factors and Datums}

Conversion Factors

Inch/Pound to SI

\begin{tabular}{|c|c|c|}
\hline Multiply & By & To obtain \\
\hline \multicolumn{3}{|c|}{ Length } \\
\hline inch (in.) & 2.54 & centimeter $(\mathrm{cm})$ \\
\hline inch (in.) & 25.4 & millimeter (mm) \\
\hline foot (ft) & 0.3048 & meter (m) \\
\hline mile (mi) & 1.609 & kilometer (km) \\
\hline \multicolumn{3}{|c|}{ Area } \\
\hline acre & 4,047 & square meter $\left(\mathrm{m}^{2}\right)$ \\
\hline acre & 0.4047 & hectare (ha) \\
\hline acre & 0.004047 & square kilometer $\left(\mathrm{km}^{2}\right)$ \\
\hline square mile $\left(\mathrm{mi}^{2}\right)$ & 259.0 & hectare (ha) \\
\hline square mile $\left(\mathrm{mi}^{2}\right)$ & 2.590 & square kilometer $\left(\mathrm{km}^{2}\right)$ \\
\hline \multicolumn{3}{|c|}{ Flow rate } \\
\hline cubic foot per second $\left(\mathrm{ft}^{3} / \mathrm{s}\right)$ & 0.02832 & cubic meter per second (m³/s) \\
\hline $\begin{array}{l}\text { cubic foot per second per square } \\
\text { mile }\left[\left(\mathrm{ft}^{3} / \mathrm{s}\right) / \mathrm{mi}^{2}\right]\end{array}$ & 0.01093 & $\begin{array}{l}\text { cubic meter per second per square } \\
\text { kilometer }\left[\left(\mathrm{m}^{3} / \mathrm{s}\right) / \mathrm{km}^{2}\right]\end{array}$ \\
\hline
\end{tabular}

Temperature in degrees Fahrenheit $\left({ }^{\circ} \mathrm{F}\right)$ may be converted to degrees Celsius $\left({ }^{\circ} \mathrm{C}\right)$ as follows:

$$
{ }^{\circ} \mathrm{C}=\left({ }^{\circ} \mathrm{F}-32\right) / 1.8
$$

Datums

Vertical coordinate information is referenced to the North American Vertical Datum of 1988 (NAVD 88).

Horizontal coordinate information is referenced to the North American Datum of 1983 (NAD 83).

Elevation, as used in this report, refers to distance above the vertical datum. 


\title{
Estimating Low-Flow Frequency Statistics and Hydrologic Analysis of Selected Streamflow-Gaging Stations, Nooksack River Basin, Northwestern Washington and Canada
}

\author{
By Christopher A. Curran and Theresa D. Olsen
}

\begin{abstract}
Low-flow frequency statistics were computed at 17 continuous-record streamflow-gaging stations and 8 miscellaneous measurement sites in and near the Nooksack River basin in northwestern Washington and Canada, including the $1,3,7,15,30$, and 60 consecutive-day low flows with recurrence intervals of 2 and 10 years. Using these low-flow statistics, 12 regional regression equations were developed for estimating the same low-flow statistics at ungaged sites in the Nooksack River basin using a weighted-least-squares method. Adjusted $R^{2}$ (coefficient of determination) values for the equations ranged from 0.79 to 0.93 and the root-mean-squared error (RMSE) expressed as a percentage ranged from 77 to 560 percent.

Streamflow records from six gaging stations located in mountain-stream or lowland-stream subbasins of the Nooksack River basin were analyzed to determine if any of the gaging stations could be removed from the network without significant loss of information. Using methods of hydrograph comparison, daily-value correlation, variable space, and flow-duration ratios, and other factors relating to individual subbasins, the six gaging stations were prioritized from most to least important as follows: Skookum Creek (12209490), Anderson Creek (12210900), Warm Creek (12207750), Fishtrap Creek (12212050), Racehorse Creek (12206900), and Clearwater Creek (12207850). The optimum streamflowgaging station network would contain all gaging stations except Clearwater Creek, and the minimum network would include Skookum Creek and Anderson Creek.
\end{abstract}

\section{Introduction}

The Nooksack River and its tributaries (fig. 1) support an abundance of wildlife unique to the Northwest region and are a major component of Puget Sound fisheries, supporting stocks of native salmonid species including Chinook, Chum,
Coho, Pink, and Steelhead (Washington Department of Fish and Wildlife, 2002). The river also supplies some of the water needs for residents of Whatcom County, including the City of Bellingham with a population of 67,200 (U.S. Census Bureau, 2000), as well as industrial and agricultural uses in the county. Like other large river systems in western Washington, the Nooksack River, including its tributaries and ecosystems, faces increasing pressures from society for water demand, flood protection, and riparian land use. The health and natural functioning of the river system is of concern to all residents of the Nooksack River basin, and also is vital for maintaining the intimate connection between the river and the indigenous people of the Northwest.

The streamflow-gaging station network in the Nooksack River basin is an important asset in managing the basin's water resources as it provides the necessary data for quantifying water availability, establishing decisions on water use, and determining instream-flow requirements (Washington State Department of Ecology, 1985). At present (2009), the network in the Nooksack River basin consists of 17 streamflow-gaging stations and 8 miscellaneous measurement sites operated by the U.S. Geological Survey (USGS), Washington State Department of Ecology (Ecology), and Environment Canada (EC) (fig. 2). An additional 2 streamflow-gaging stations and 5 miscellaneous measurement sites maintained by the USGS and Ecology are located within $5 \mathrm{mi}$ of the basin boundary (ig. 2). Streamflow-gaging stations are automated to monitor streamflow, usually at 15 -minute intervals, whereas miscellaneous measurement sites are locations where discrete measurements of streamflow have been made periodically over time. Streamflow-gaging stations and miscellaneous measurement sites in and near the basin, as well as the years of record and operating agencies, are shown in table 1.

In 1998, under an agreement with the U.S. Bureau of Indian Affairs, the USGS installed six streamflow-gaging stations for the purpose of monitoring the streamflow of tributaries in the Nooksack River basin. This agreement with the USGS was later transferred to the Lummi Nation, an indigenous tribe of Native Americans in western Washington. 


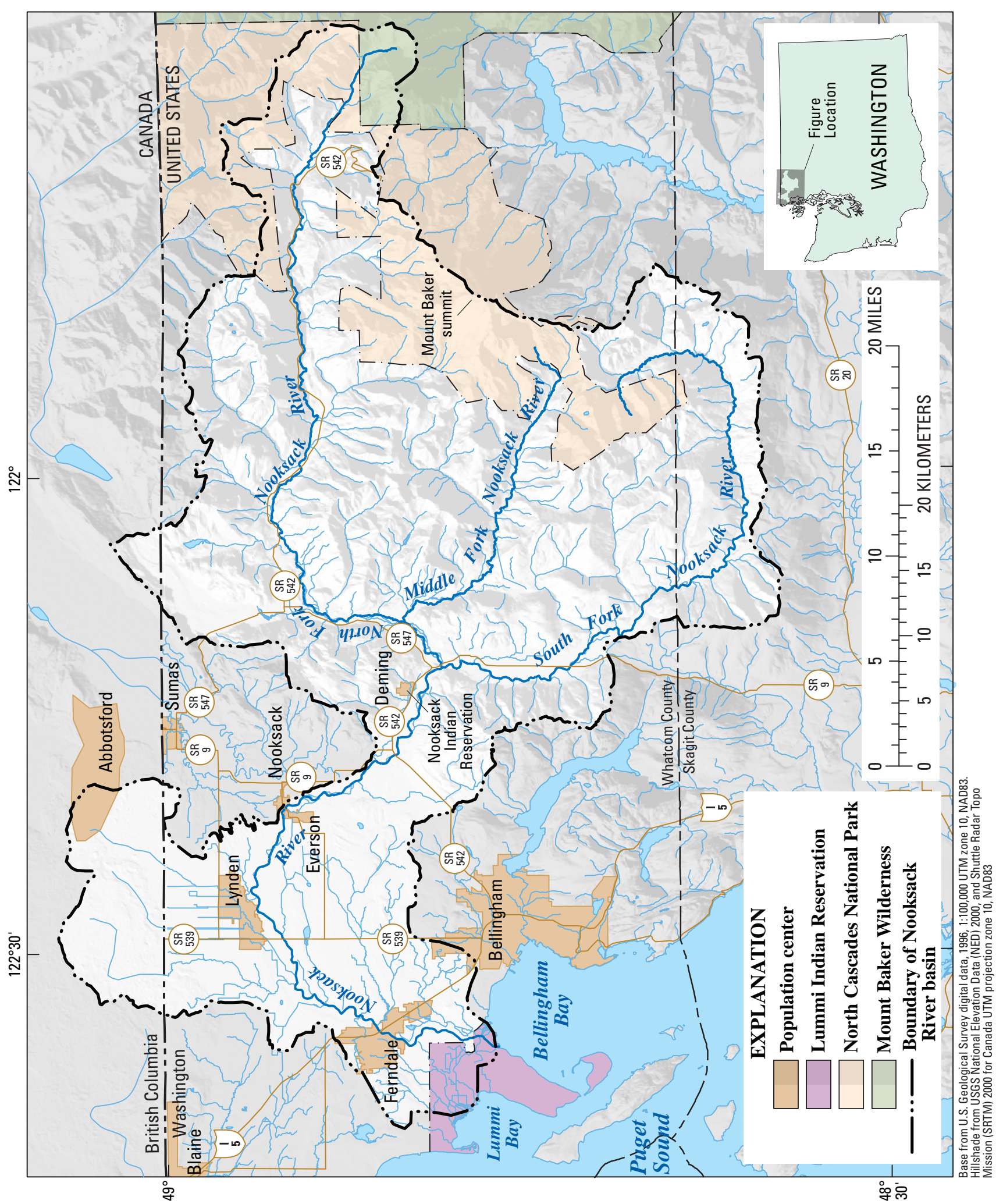

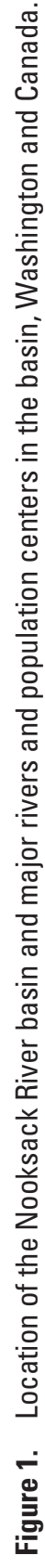




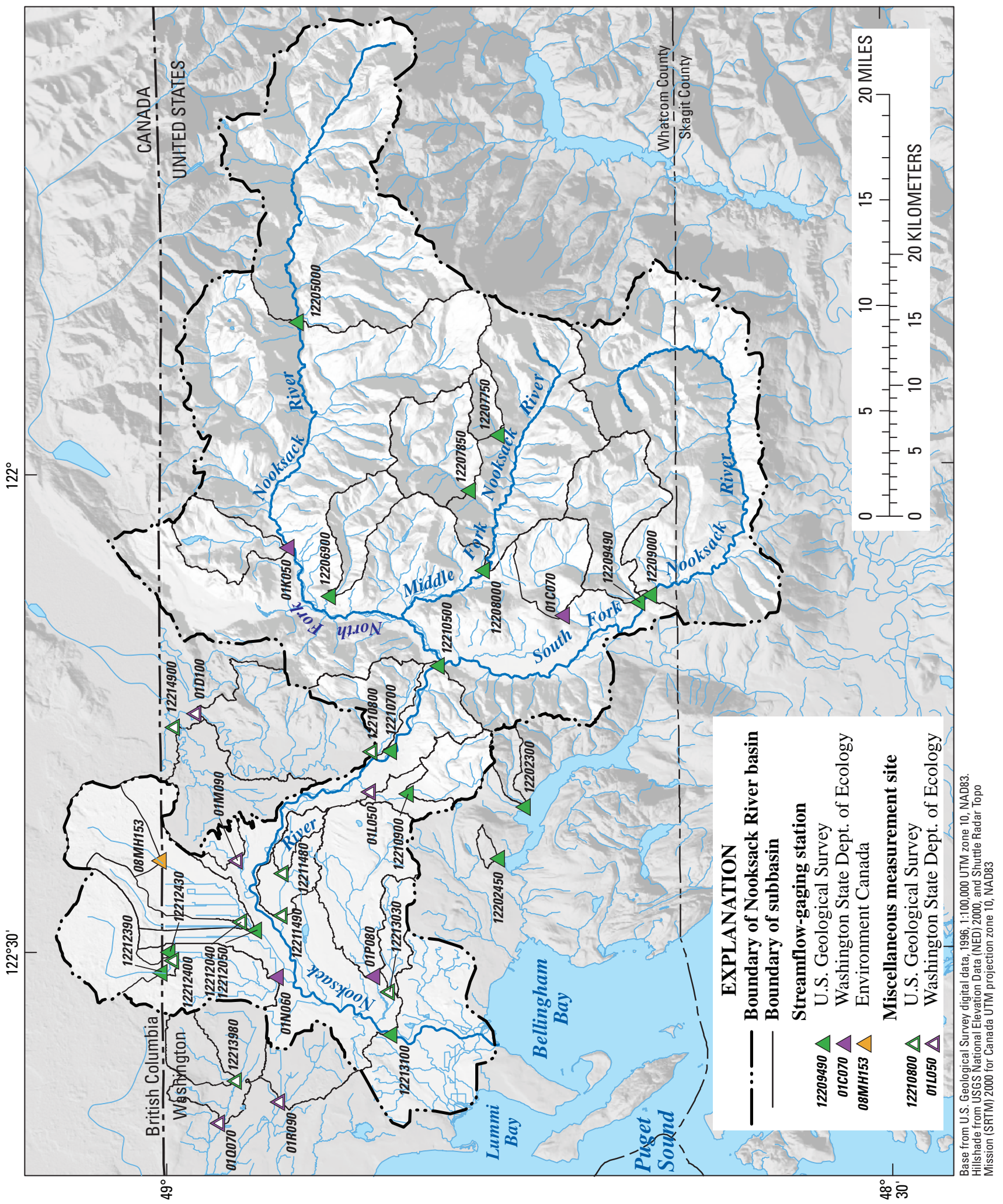

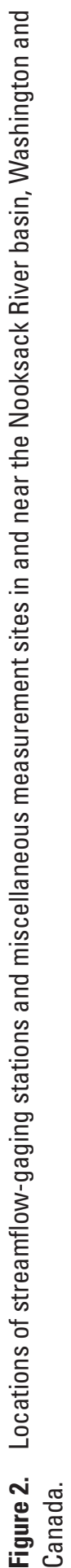




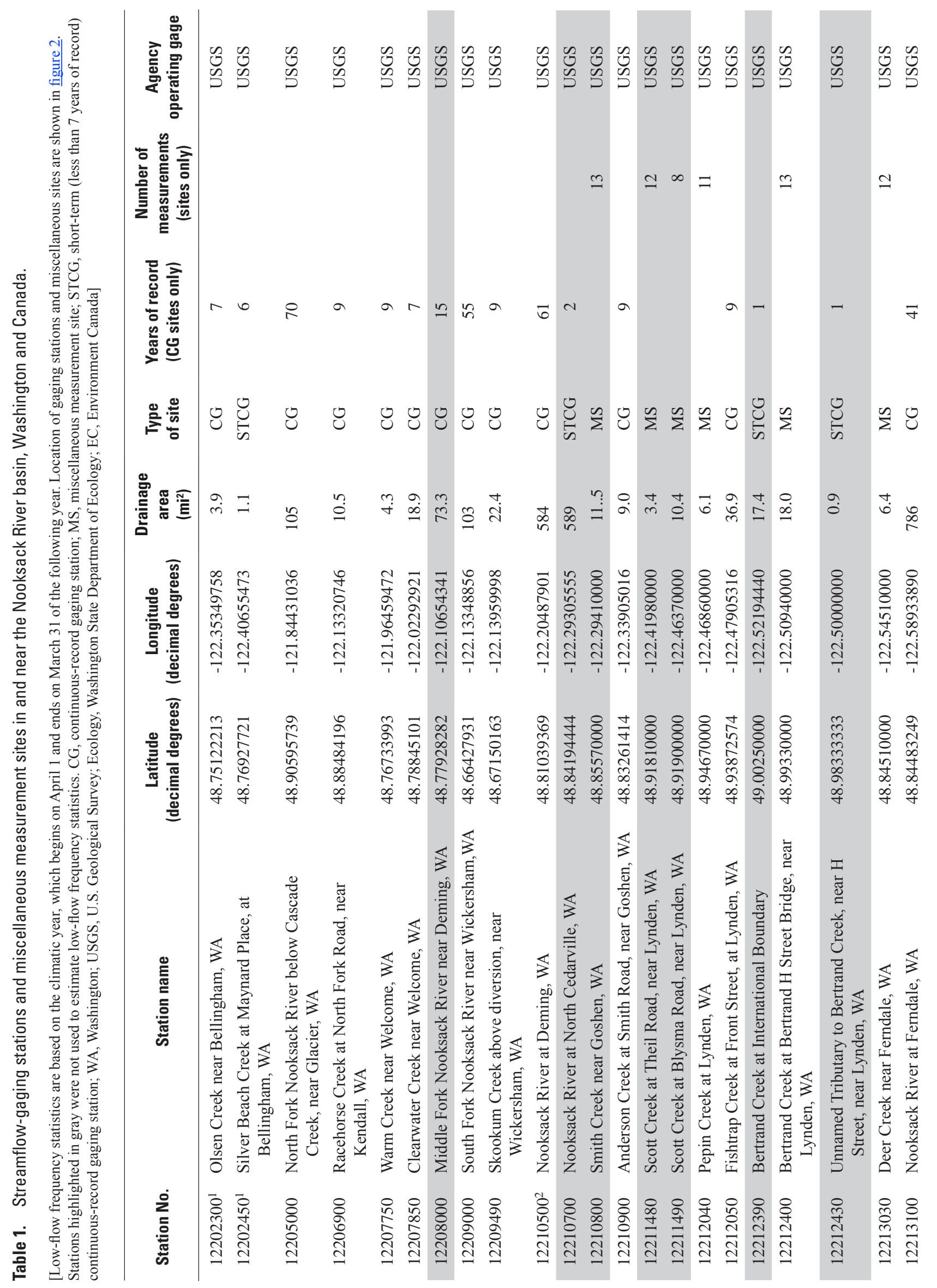




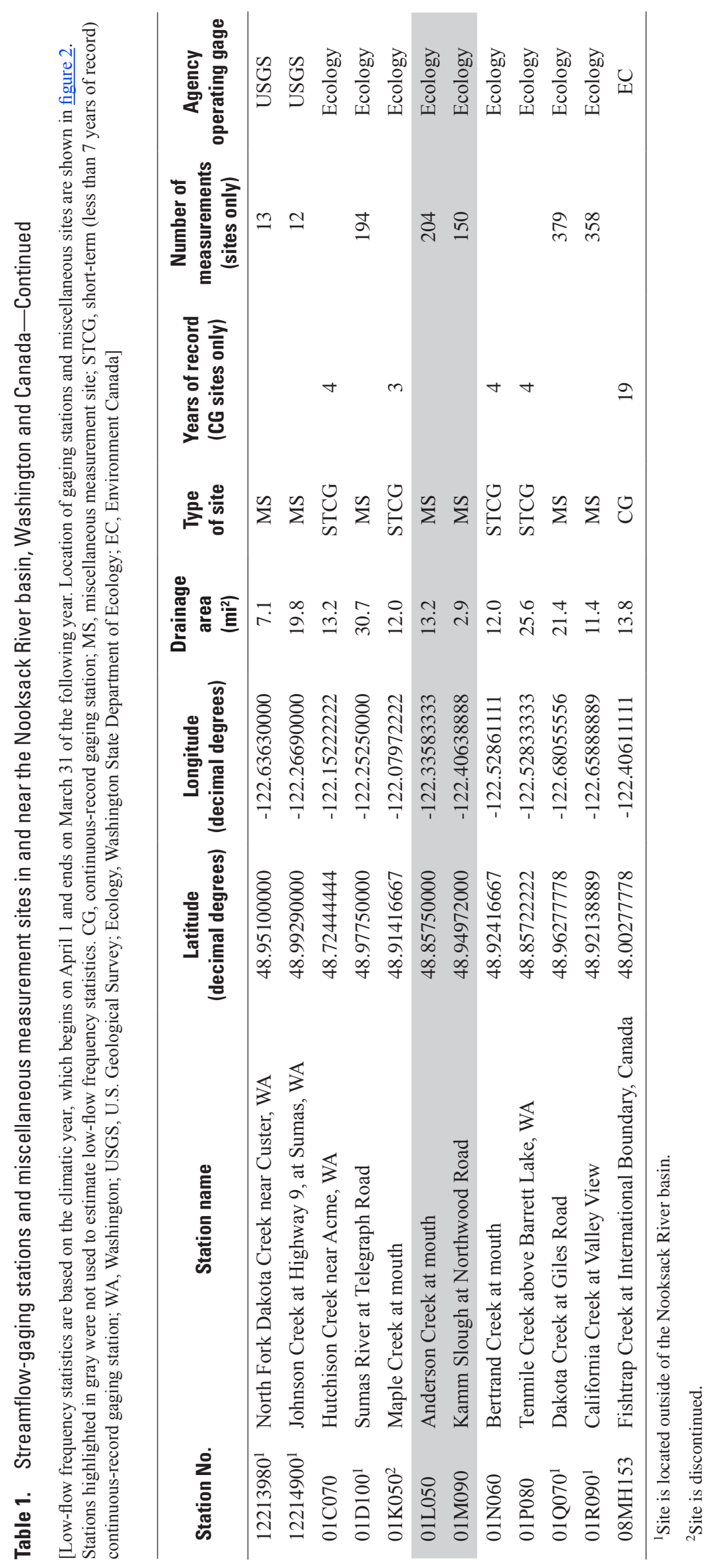


The Lummi Nation has funded the operation of the six streamflow-gaging stations from 2000 to the present (2009) and has requested that the USGS provide an analysis of the accumulated data with a focus on low flows, as well as determine whether some of the six stations could be removed from the network without significant loss of information.

\section{Purpose and Scope}

This report summarizes streamflow data collected in the Nooksack River basin, including data from six gaging stations funded by the Lummi Nation for the purpose of developing regional regression equations to estimate low-flow frequency statistics at ungaged sites. The report also evaluates the redundancy in streamflow data between the six gaging stations and their importance for developing future regional regression equations.

Low-flow frequency statistics, such as the 7Q10 (defined as the mean low streamflow that occurs over 7 consecutive days with a 10-year recurrence interval) were calculated for 17 of the streamflow-gaging stations in and near the basin. These statistics also were estimated for 8 miscellaneous measurement sites based on concurrent streamflow at index sites (gaging stations that are nearby or hydrologically similar) using established methods. Subbasin drainage areas were then delineated upstream of all streamflow sites in the study and basin attributes such as mean annual precipitation, percent forest cover, and percent surficial geology classified as bedrock, were determined using Geographic Information System (GIS) methods.

Using the statistics and basin attributes determined for all streamflow sites in the network, regional regression equations were developed for estimating low-flow frequency statistics at ungaged streams in the Nooksack River basin. Performance metrics such as the root-mean-squared error (RMSE) and the adjusted coefficient of determination ( $R^{2}$ adjusted) were calculated for each of the regression equations developed.

In evaluating the six streamflow-gaging stations funded by the Lummi Nation, the subbasins for each of the gaging stations were characterized based on land use, channel processes, and the stream hydrograph. The Pearson's correlation coefficient, $r$, was examined between the seasonal daily mean streamflow records for each of the gaging stations to show where redundancy in daily streamflow information exists. The basin attributes for each gaging station as well as flow-duration ratios and variable space methods were examined to qualitatively assess the priority of each of the six gaging stations for remaining in the overall streamflow-gaging station network for the basin.

\section{Description of Study Area}

Located primarily in northwestern Washington, the Nooksack River basin (fig. 1) encompasses $822 \mathrm{mi}^{2}$ of mostly forested land, and ranges in elevation from $10,800 \mathrm{ft}$, the summit of Mount Baker in the Cascade Range, to sea level at the shores of Puget Sound. The Nooksack River is the product of three major tributaries: the North Fork, Middle Fork, and South Fork Nooksack Rivers (fig. 1). The largest of these is the North Fork, and when added to the length of the mainstem, the entire river runs westward about 75 river miles from its headwaters in the mountains to Puget Sound. The basin is bounded to the north by mountains forming the Fraser River valley in Canada and to the south by mountains forming the Skagit River valley. Of all Washington State rivers flowing into Puget Sound, the Nooksack River is the third largest, with an average streamflow of $3,840 \mathrm{ft}^{3} / \mathrm{s}$ (U.S. Geological Survey, 2008).

The Nooksack River basin connects the contrasting landscapes of a tectonically and volcanically active mountain range and glaciated lowland. The Cascade Range is a magmatic arc formed by the subduction of an oceanic plate beneath the continental crust and its western edge is an assemblage of sedimentary and volcanic rocks of Eocene through early Miocene age (Jones, 1999). The comparatively flat Puget Lowland lies within the forearc basin formed between the colliding plates and has been largely sculpted by numerous Pleistocene glaciations which deposited thick sedimentary layers of glacial outwash, interspersed with finer layers of till (Dragovich and others, 1997b). Presentday surficial geology in the basin reflects the history of mountain-building, erosional processes such as landslides and lahars, and fluvial processes that erode, transport and deposit sediment in post-glacial terrain (Linneman and others, 2007).

Climate in the region is maritime and heavily influenced by moist, offshore weather patterns originating in the Pacific Ocean and moving inland. The region receives about 67 percent of annual precipitation from October to March (National Oceanic and Atmospheric Administration, 2007), with orographic uplift causing more precipitation at high elevations, often as snow in the mountains. Winters in the region typically are wet and mild in the lowland, while summers are warmer and relatively dry. During the most recent climate-normal period (1971-2000), mean annual precipitation in the Nooksack River basin was about 90 in. and ranged from about $32 \mathrm{in}$. near the mouth of the river to about 220 in. near the crest of Mount Baker (PRISM Climate Group, 1998).

About 70 percent of the Nooksack River basin is forested (primarily by coniferous trees in the mountains) while in the lowland, agriculture (crops and dairy) is the dominant land use accounting for 16 percent of total land cover (Multi-Resolution Land Characteristics Consortium, 2001). Urbanized areas in the basin are largely concentrated in or around the population centers of Ferndale, Lynden, Bellingham (which is largely outside of the basin), and Abbotsford, British Columbia. The population in the Nooksack River basin was about 55,000 in 2000 and increased about 25 percent from 1990 to 2000 (U.S. Census Bureau, 2000). 


\section{Previous Investigations}

The earliest investigation of low-flow characteristics for streams in the Puget Sound region was conducted by Hidaka (1973). In that study, streamflow records from 150 gaging stations throughout the Puget Sound region were used to determine low-flow frequency statistics. Indexes such as the low-flow yield index (ratio of 7Q2 to drainage area, where the $7 \mathrm{Q} 2$ is defined as the mean low streamflow that occurs over 7 consecutive days with a 2-year recurrence interval) and the base-flow index (ratio of 7Q2 to mean annual streamflow) also were calculated and related qualitatively to basin characteristics such as climate, topography, and geology. Subsequent researchers determined low-flow frequency curves for streams in selected areas of western Washington such as the Olympic and Kitsap Peninsulas, and used simple regression methods to estimate low-flow frequency statistics at miscellaneous measurement sites (Cummans, 1976; Haushild and LaFrance, 1977).

Although no previous studies have documented the development of regional regression equations for estimating low-flow frequency statistics at ungaged sites in western Washington, numerous such studies have recently been conducted throughout the country at the State-wide scale (Ries and Friesz, 2000; Hortness, 2006; Funkhouser and others, 2008; and Risley and others, 2008).

\section{Low-Flow Frequency Statistics at Continuous-Record Gaging Stations and Miscellaneous Measurement Sites}

Low-flow frequency statistics are useful for estimating the probability of water availability in streams during critical low-flow periods when conflicting demands for water, for example the demands of water supply versus ecosystem needs, are likely to exist. These statistics commonly are used by Federal, State and local agencies in water-use planning and management, as well as in establishing regulatory policies relating to instream flows and water quality. Lowflow frequency statistics such as the 7Q10 (defined as the mean low streamflow that occurs over 7 consecutive days with a 10-year recurrence interval) are determined from the mean of consecutive-day low flows of a particular stream, usually during a climatic year (April 1 through March 31 of the following year) to avoid artificially separating low-flow periods by water year. The recurrence interval of a particular consecutive-day low-flow event is calculated by fitting the annual low-flow series to a log-Pearson Type III distribution (Riggs, 1972). In general, it is desirable to compute lowflow frequency statistics such as the 7Q10 at streamflowgaging stations with 10 or more years of streamflow record, although previous studies have made exceptions based on the range of streamflow conditions during the period of record (Hortness, 2006). When the streamflow record for a gaging station satisfies a length-of-record criterion, it is considered a continuous-record gaging station (CG), and a streamflow record that falls short of the criterion is referred to as a 'short-term' continuous-record gaging station (STCG) (Ries and Friesz, 2000). Low-flow frequency statistics also can be estimated at miscellaneous measurement sites provided that a sufficient number of measurements have been made during baseflow periods (Funkhouser and others, 2008; Risley and others, 2008). Whereas low-flow frequency statistics can be computed directly from the record of daily streamflow at a CG station, additional methods must be used to estimate similar statistics at miscellaneous measurement sites.

In western Washington, most annual consecutive-day low flows occur during the late summer or early autumn, and in small or intermittent streams, low-flow frequency statistics can have values of zero. In this study, low-flow frequency statistics were determined at 15 streamflow-gaging stations in the Nooksack River basin, 2 gaging stations just outside of the basin, and 8 miscellaneous measurement sites. Because of the limited number of gaging stations in the Nooksack River basin, CG stations in this study were defined as gaging stations with 7 or more years of record covering a broad range of streamflow conditions, and stations with less than 7 years of record were defined as STCG stations. All miscellaneous measurement sites with 10 or more measurements made during baseflow periods were initially considered in the analysis. Stations with known upstream diversions or significant regulation were not included in the analysis. For example, USGS gaging station 12208000 on the Middle Fork of the Nooksack River was not included because significant withdrawals for water supply are made upstream of the gaging station. At stations where small upstream diversions or regulation may exist but are undocumented (for example, stations in the lowland areas where irrigation uses may occur), low-flow frequency statistics were determined and used in the analysis based on the assumption that effects of the upstream modifications were minor. The presence of trends in streamflow data in the Nooksack River basin was not tested in this analysis and it was assumed that the annual low flows recorded at individual stations are independent and representative of long-term streamflow conditions.

At STCG stations, the streamflow record was extended to 7 years using the Maintenance of Variance Extension version 1.0 (MOVE.1) statistical method (Hirsch, 1982). In this method, a log-linear relation of daily streamflow was developed based on the overlapping streamflow records of the STCG station and a nearby or hydrologically similar CG station with a longer record (also referred to as an index station). The relation between daily streamflow at both stations was used to extend the record at the STCG station. Unlike a simple linear regression, which results in streamflow estimates that are biased low in their variance, MOVE. 1 preserves the probability distribution of the estimates (Hirsch, 1982). 
At miscellaneous measurement sites, the MOVE.1 method also was used to estimate streamflow statistics (such as the 7 Q10) based on the log-linear relation between 10 or more streamflow measurements at the miscellaneous measurement site and concurrent flows at an index station. The calculated low-flow frequency statistics for 12 CG stations, 5 STCG stations, and 8 miscellaneous measurement sites are shown in table 2.

\section{Estimating Low-Flow Frequency Statistics at Ungaged Sites Using Regional Regression Equations}

\begin{abstract}
Water managers, regulators, and scientists are often interested in streamflow information at locations in a stream network for which measurements do not exist. The development of regional regression equations for the purpose of estimating streamflow statistics at ungaged sites is a common practice and has been well documented in previous studies in the Pacific Northwest (Hortness, 2006; Risley and others, 2008) and throughout the United States (Ries and Friesz, 2000; Funkhouser and others, 2008). Ideally, the development of regional regression equations involves an existing network of many streamflow-gaging stations with long periods of record for which accurate streamflow statistics of natural flow conditions can be determined. In practice, the number of gaging stations representing natural flow conditions is limited, the gaging-station network is often biased toward representing larger streams or rivers and the geographic placement of the network is unevenly distributed.

For the Nooksack River basin, regional regression equations were developed for estimating the low-flow frequency statistics for the $1,3,7,15,30$, and 60 consecutiveday low flows with recurrence intervals of 2 and 10 years at ungaged sites in the basin. All equations were developed from the streamflow statistics previously determined at $12 \mathrm{CG}$ stations, 5 STCG stations, and 8 miscellaneous measurement sites, and the basin characteristics at each site.
\end{abstract}

\section{Methods of Regression}

Multiple linear regression methods were used to develop relations between streamflow statistics such as the 7Q10 (the 7-day low-flow with a 10-year recurrence interval), and the 30Q2 (the 30-day low flow with a 2-year recurrence interval) and basin characteristics such as drainage area and mean basin elevation. The weighted-multiple-linear-regression model (WREG) software (Ken Eng, U.S. Geological Survey, written comm., 2009) was used to develop the regression equations and three types of multiple linear regression methods were considered — ordinary least squares (OLS), weighted-least squares (WLS), and generalized-least squares (GLS). The most common regression method, OLS, assumes that streamflow statistics from all sites are equivalent in accuracy. However, low-flow frequency statistics computed from continuous-record gaging stations with longer periods of record are likely to be more accurate than statistics from stations with shorter periods of record, and continuousrecord stations of any length are likely to be more accurate than statistics estimated at miscellaneous measurement sites. Because the streamflow sites on which the regression models are based are not equivalent in their periods of record, the OLS method was not used. The WLS and GLS methods are preferred for hydrologic regression equations because these methods allow for giving more weight (influence in shaping the regression model) to streamflow sites with more reliable statistics (longer record, smaller variance). In the GLS method, weight also is assigned based on the correlation (similarity) of streamflow records among sites. For example, sites in close proximity may respond similarly to hydrologic events compared to sites that are farther apart. In GLS, less weight is assigned to sites that are highly correlated, and more weight is given to sites that represent different hydrologic responses. When all sites are located in the same basin, substantial inherent correlation among sites reduces the power of the GLS method. This was observed among sites in the Nooksack River basin (particularly during the summer season) and for this reason, the WLS method was selected over the GLS method.

\section{Basin Attributes}

Basin attributes were derived from a combination of GISbased sources and previous studies in the Puget Sound region. The data source for each basin attribute and the 26 attributes considered for use in the regression equations are shown in table 3. The basin attributes for all continuous-record gaging stations and miscellaneous measurement sites considered in this study are shown in table 4. Only a limited number of basin attributes were selected as explanatory variables in the final regression equations to avoid 'over-fitting' the model (that is, adding complexity without improving model performance). Some researchers have suggested limiting the number of explanatory variables in a regression equation to one variable for every 10-15 observations (Ken Eng, U.S. Geological Survey, oral commun., 2009), and this approach was used in the present study.

Basin attributes were first screened for multicollinearity, or the degree of correlation between explanatory variables, to determine which basin attributes should be incorporated into the regression equations. For example, a high correlation was found between the basin attributes of mean elevation and mean annual precipitation, likely due to orographic uplift that causes greater precipitation at high elevations. In this case, multicollinearity precludes both of these attributes from being used as variables in the same regression equation. Bivariate plots were then generated between streamflow statistics and basin attributes to determine if variable transformations, such as logarithms, would improve the linearity of relations. 


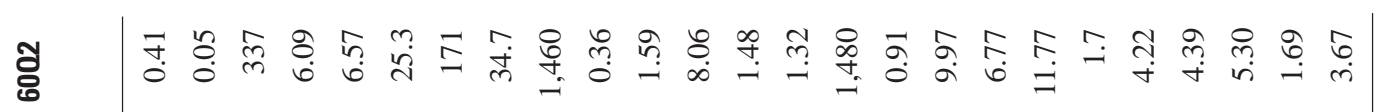

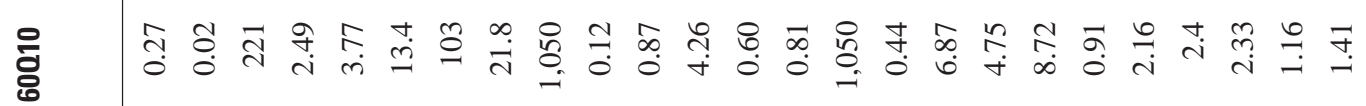

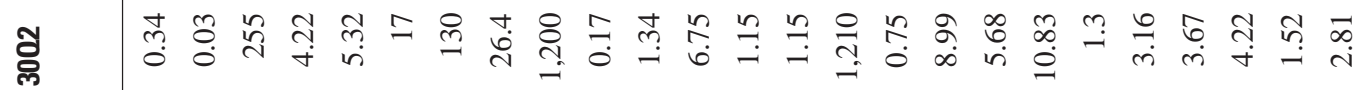
임 $\quad$ 중 윰

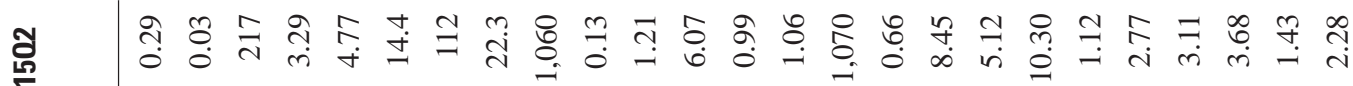

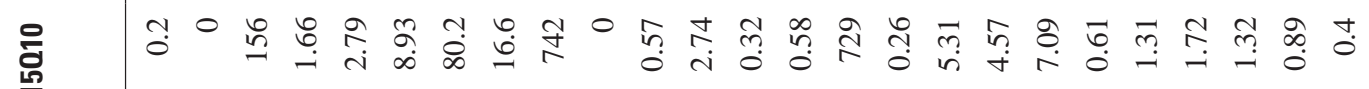

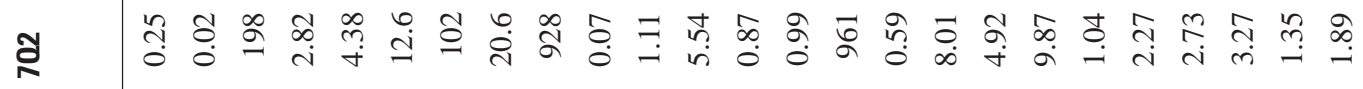

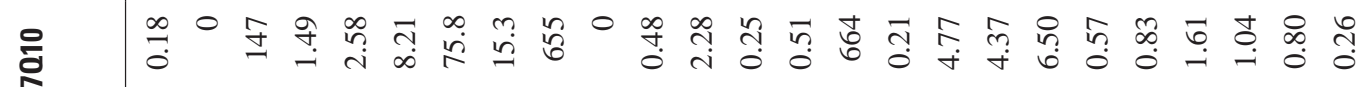

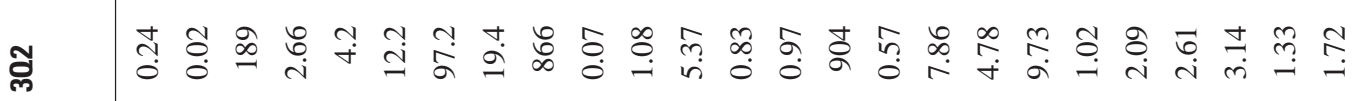

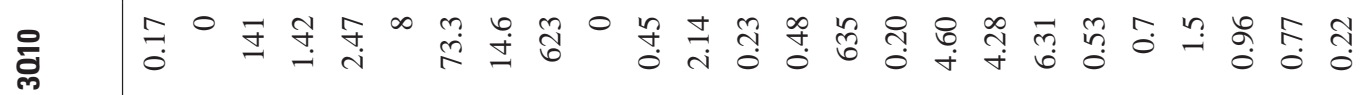

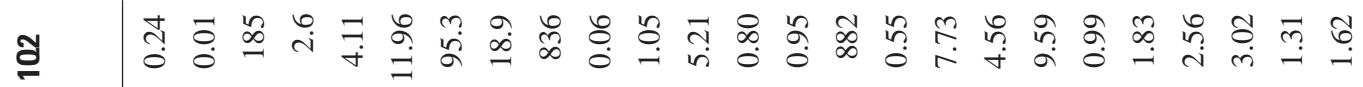

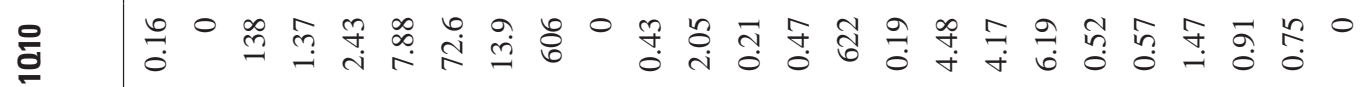

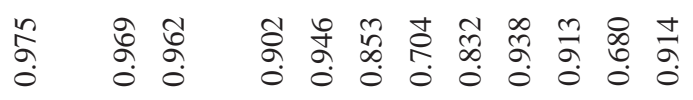

$\Rightarrow \quad \mathfrak{7} \stackrel{\rightarrow}{7}$ ซ

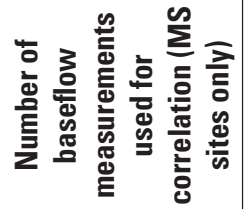

\section{8
$\stackrel{8}{1}$
సิ}


Table 3. Basin attributes and their source data considered in the regional regression analysis for estimating low-flow frequency statistics at ungaged sites, Nooksack River basin, Washington and Canada.

[Data source: 1, U.S. Geological Survey, Streamstats for Washington at http://water.usgs.gov/osw/streamstats/Washington.html; 2, PRISM Climate Group, Oregon State University, http://www.prismclimate.org, accessed April 22, 2009; 3, Vaccaro and others, 1998, http://pubs.er.usgs.gov/usgspubs/pp/pp1424D; 4, Multi-Resolution Land Characteristics Consortium (MRLC), National Land Cover Database (NLCD) 2001 at http://www.mrlc.gov/index.php; 5, Mission topographic map (2000), scale 1:50,000, Centre for Topographic Information, Natural Resources Canada; 6, New Westminster topographic map (1989), scale 1:50,0000, Canada Centre for Mapping, Department of Energy, Mines, and Resources; and 7, Shuttle Radar Topography Mission (SRTM) Elevation Data Set, 2002, http://seamless.usgs.gov]

\begin{tabular}{|c|c|c|}
\hline Basin attribute & Description & Data source \\
\hline Latitude & Latitude, NAD83 & 1 \\
\hline Longitude & Longitude, NAD83 & 1 \\
\hline Drainage area & Drainage area, in square miles & 1 \\
\hline Precipitation & Mean annual precip (1971-2000), in inches & 2 \\
\hline Precipitation, minimum & Minimum annual precipitation (1971-2000), in inches & 2 \\
\hline Precipitation, maximum & Maximum annual precipitation (1971-2000), in inches & 2 \\
\hline Precipitation, September & Mean September precipitation (1971-2000), in inches & 2 \\
\hline Relief & Relief (maximum minus minimum basin elevation), in feet & 1 and 7 \\
\hline Elevation & Mean basin elevation, in feet & 1 and 7 \\
\hline Elevation, maximum & Maximum basin elevation, in feet & 1 and 7 \\
\hline Elevation, minimum & Minimum basin elevation, in feet & 1 and 7 \\
\hline Slope & Mean basin slope, in percent & 1 and 7 \\
\hline Slope, greater than 30 percent & Percentage of area with slope greater than 30 percent & 1 and 7 \\
\hline $\begin{array}{l}\text { Slope, greater than } 30 \text { percent } \\
\text { facing north }\end{array}$ & Percentage of area with slope greater than 30 percent and facing north & 1 and 7 \\
\hline Bedrock & Percentage of area with surficial geology classified as bedrock & 3 \\
\hline Fine-grained & $\begin{array}{l}\text { Percentage of area with surficial geology classified as fine-grained unconsolidated } \\
\text { sediments }\end{array}$ & 3 \\
\hline Coarse-grained & $\begin{array}{l}\text { Percentage of area with surficial geology classified as coarse-grained unconsolidated } \\
\text { sediments }\end{array}$ & 3 \\
\hline Alluvial & Percentage of area with surficial geology classified as alluvial sediments & 3 \\
\hline Open water & Percentage of area with land cover classified as open water & $4,5,6$ \\
\hline Ice/snow & Percentage of area with land cover classified as ice/snow & $4,5,6$ \\
\hline Urban & Percentage of area with land cover classified as developed land & $4,5,6$ \\
\hline Barren & Percentage of area with land cover classified as barren land & $4,5,6$ \\
\hline Forest & Percentage of area with land cover classified as forest & $4,5,6$ \\
\hline Shrub/scrub & Percentage of area with land cover classified as shrub/scrub & $4,5,6$ \\
\hline Agriculture/grassland/pasture & Percentage of area with land cover classified as agriculture/grassland/pasture & $4,5,6$ \\
\hline Wetlands & Percentage of area with land cover classified as wetlands & $4,5,6$ \\
\hline
\end{tabular}




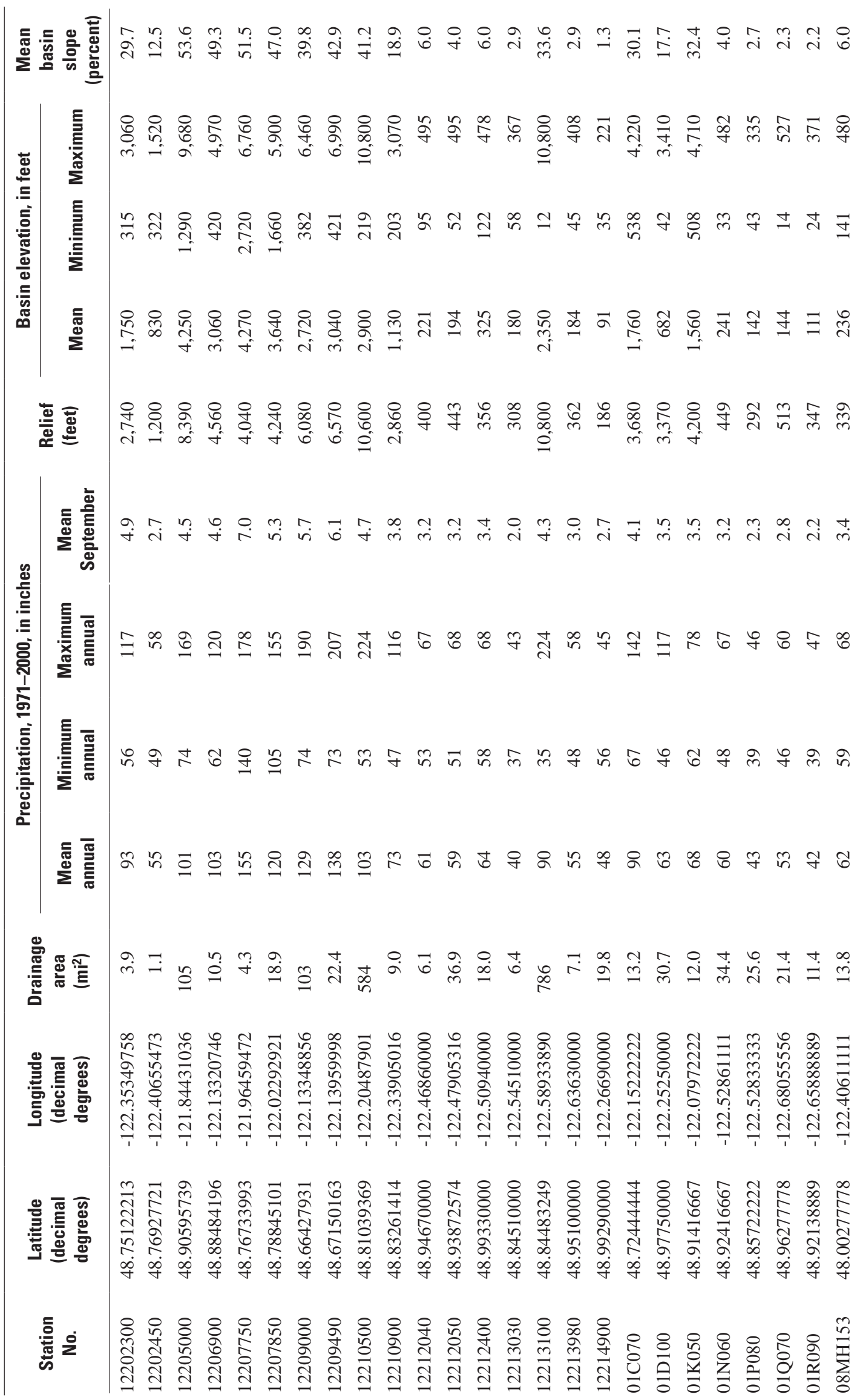




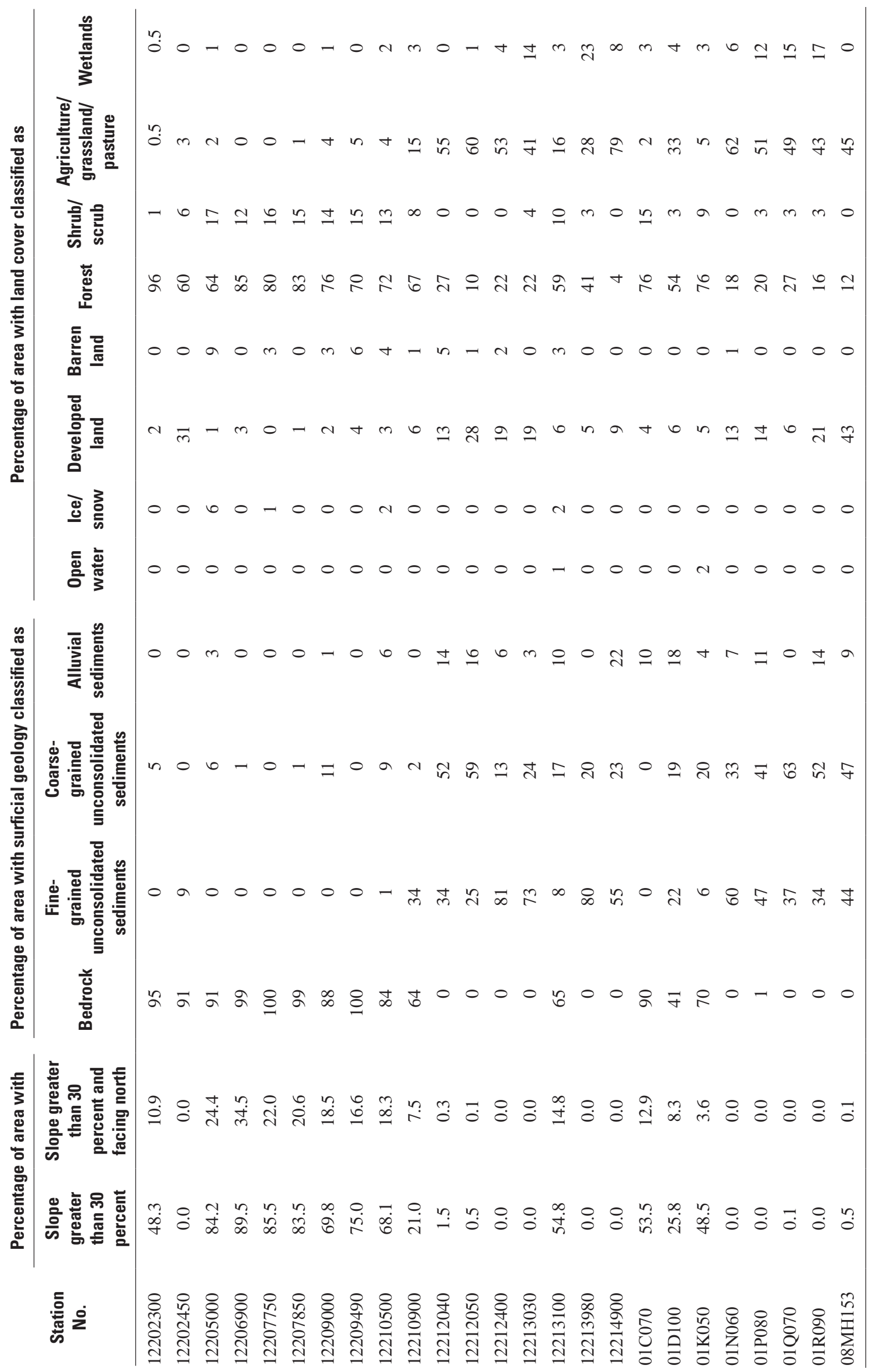


Base 10 logarithmic (referred to as $\log$ ) transformations of streamflow $(\mathrm{Q})$ and drainage area (DA) were justified, and for convenience in the final equations, all basin elevations were expressed in units of thousands of feet. Finally, a stepwiseregression procedure was performed using S-Plus ${ }^{\circledR}$ statistical software (TIBCO Software Inc., 2008) wherein preliminary equations were generated for calculating streamflow statistics from all combinations of basin attributes. Through iteration and screening of Mallow's Cp statistic (a metric that rewards accuracy in the model, while penalizing complexity), the stepwise procedure removed those basin attributes that contributed least to the explanatory power of the regression equation. By repeating the stepwise procedure many times and for different combinations of basin attributes, certain attributes outperformed others and were retained as variables in the final regression equations. For example, although mean annual precipitation $(\mathrm{P})$ commonly is found in regression equations for estimating high flows, it was outperformed by mean basin elevation (E). The basin attributes used in the final regression equations were DA and $\mathrm{E}$ and these were determined on the basis of performance metrics (RMSE, $R^{2}$, and $\mathrm{Cp}$ ) computed in the stepwise procedure.

\section{Regression Equations}

Regression equations were developed for 12 low-flow frequency statistics, such as the 7Q10 and the 30Q2. The regression equations for estimating flow statistics at ungaged sites in the Nooksack River basin and their performance metrics are shown in table 5 . Because the regressions involved log transformations of flow statistics, zero values (for example, a 7Q10 equal to 0) cannot be used in the regression. Ideally, estimating statistics for these sites would be done through the use of logistic regression (Hortness, 2006; Funkhouser and others, 2008) and with the availability of a large number of similar zero-flow sites. Only a few sites in the network had zero flows for some statistics. For these statistics, a value of $0.01 \mathrm{ft}^{3} / \mathrm{s}$ was added to the value of the statistic at all sites for the purpose of performing the regression. Although this approach may result in some bias, it was considered acceptable for the purposes of the study.

Table 5. Regression equations for estimating low-flow frequency statistics at ungaged sites in the Nooksack River basin, Washington and Canada.

[Low-flow statistic: $\mathbf{x Q y}$, the mean low streamflow that occurs over $\mathbf{x}$ consecutive days and has a recurrence interval of y years, in cubic feet per second; $\mathbf{R}^{\mathbf{2}}$ adjusted, coefficient of determination adjusted for the number of explanatory variables in the regression equation; RMSE, root-mean-squared error; DA, drainage area, in square miles; $\mathbf{E}$, mean basin elevation, in thousands of feet; $\mathrm{ft}^{3} / \mathrm{s}$, cubic feet per second]

\begin{tabular}{lrcccc}
\hline \multirow{2}{*}{$\begin{array}{c}\text { Low-flow } \\
\text { statistic }\end{array}$} & \multirow{2}{*}{ Regression equation } & \multirow{2}{*}{$\boldsymbol{R}^{2}$ adjusted } & \multicolumn{2}{c}{ RMSE } \\
\cline { 4 - 5 } & & & $\log _{10}\left(\mathbf{f t t}^{3} / \mathbf{s}\right)$ & percent \\
\hline $1 \mathrm{Q} 10$ & $1 \mathrm{Q} 10=0.0170(\mathrm{DA})^{1.40} \times 10^{0.216(\mathrm{E})}$ & 0.79 & 0.810 & 560 \\
$1 \mathrm{Q} 2$ & $1 \mathrm{Q} 2=0.0371(\mathrm{DA})^{1.44} \times 10^{0.146(\mathrm{E})}$ & 0.88 & 0.544 & 194 \\
3Q10 & $3 \mathrm{Q} 10=0.0176(\mathrm{DA})^{1.42} \times 10^{0.210(\mathrm{E})}$ & 0.83 & 0.549 & 198 \\
3Q2 & $3 \mathrm{Q} 2=0.0436(\mathrm{DA})^{1.40} \times 10^{0.149(\mathrm{E})}$ & 0.88 & 0.417 & 123 \\
$7 \mathrm{Q} 10$ & $7 \mathrm{Q} 10=0.0183(\mathrm{DA})^{1.43} \times 10^{0.206(\mathrm{E})}$ & 0.83 & 0.527 & 183 \\
$7 \mathrm{Q} 2$ & $7 \mathrm{Q} 2=0.0441(\mathrm{DA})^{1.40} \times 10^{0.150(\mathrm{E})}$ & 0.88 & 0.402 & 116 \\
$15 \mathrm{Q} 10$ & $15 \mathrm{Q} 10=0.0205(\mathrm{DA})^{1.45} \times 10^{0.190(\mathrm{E})}$ & 0.83 & 0.524 & 181 \\
$15 \mathrm{Q} 2$ & $15 \mathrm{Q} 2=0.0519(\mathrm{DA})^{1.38} \times 10^{0.154(\mathrm{E})}$ & 0.91 & 0.356 & 97.9 \\
30Q10 & $30 \mathrm{Q} 10=0.0262(\mathrm{DA})^{1.44} \times 10^{0.178(\mathrm{E})}$ & 0.88 & 0.442 & 134 \\
30Q2 & $30 \mathrm{Q} 2=0.564(\mathrm{DA})^{1.38} \times 10^{0.162(\mathrm{E})}$ & 0.91 & 0.343 & 92.9 \\
60Q10 & $60 \mathrm{Q} 10=0.0348(\mathrm{DA})^{1.40} \times 10^{0.185(\mathrm{E})}$ & 0.91 & 0.354 & 97.1 \\
60Q2 & $60 \mathrm{Q} 2=0.0716(\mathrm{DA})^{1.35} \times 10^{0.182(\mathrm{E})}$ & 0.93 & 0.296 & 76.9 \\
\hline
\end{tabular}




\section{Accuracy and Limitations}

In developing regression equations, the number of STCG stations (5) and miscellaneous measurement sites (8) were relatively large compared to the total number of sites used in this analysis (25). Determining estimates of lowflow frequency statistics at STCG stations and miscellaneous measurement sites required the selection of a nearby or hydrologically similar CG station to serve as an index station. Because most STCG stations and miscellaneous measurement sites were located in the lowland portion of the basin and the number of CG stations in the lowland was small (3 stations), the same index station was used in estimating low-flow frequency statistics at multiple STCG stations and miscellaneous measurement sites. Although this fact created undesirable correlation in the data, the benefits of retaining STCG stations and miscellaneous measurement sites (representing lowland hydrology) in the analysis outweighed the disadvantages of their removal.

The error for each regression equation was quantified by the RMSE, which is based on the difference between the value of the observed low-flow frequency statistic at each site and the value estimated by the regression equation. (The observed low-flow frequency statistic is defined as the low-flow frequency statistic computed from measured streamflows.) Because the regression equations were developed in log units, the RMSE was calculated in $\log$ units $\left[\log \left(\mathrm{ft}^{3} / \mathrm{s}\right)\right]$, and also expressed as a percentage of the observed low-flow frequency statistic. The RMSE expressed as a percentage ranged from 77 to 560 percent (table 5). The smallest RMSE expressed as a percentage was for the 60Q2 statistic (the mean low streamflow for 60 consecutive days with a 2-year recurrence interval) and the largest was for the 1Q10 (the mean low streamflow for 1 day with a 10 -year recurrence interval). For a given recurrence interval, the relative errors decreased for low-flow frequency statistics of longer duration. The largest source of error generally came from sites with low-flow frequency statistics of zero, such as Anderson Creek (12210900). This finding suggests that when using the regression equations at stream sites with a potential for zero or small (less than $0.1 \mathrm{ft}^{3} / \mathrm{s}$ ) low-flow frequency statistics, large relative errors may exist in the estimated low-flow frequency statistics. Although removing Anderson Creek from the regression models reduced the relative RMSE, the influence of this site on the regression equation coefficients as determined by WREG was small relative to other sites.
The regression equations developed in this report were based on streamflow data recorded at sites in or just outside of the Nooksack River basin and should not be used to estimate low-flow frequency statistics at sites outside of the basin. Furthermore, although the stream sites considered in this study contained a large range of values for basin attributes (drainage area and mean basin elevation) used in the regression, the equations may not be appropriate for sites with basin attributes outside of the range of values used in developing the equations.

\section{Hydrologic Analysis of Selected Streamflow-Gaging Stations}

Streamflow-gaging stations in six subbasins of the Nooksack River basin (fig. 3) are operated by the USGS in cooperation with the Lummi Nation, and are part of the larger streamflow-gaging station network in the basin. The gaging stations were individually examined in terms of their hydrologic and subbasin characteristics, and their streamflow records were analyzed collectively for patterns and redundancy in the streamflow-gaging station network.

\section{Description of Subbasins}

Subbasins in the Nooksack River basin (fig. 3) vary in size, as well as characteristics such as geology, land cover, and precipitation accumulation, but are defined herein as those basins containing first- or second-order perennial streams. On this basis, subbasins in the Nooksack River basin generally fall into one of two types - mountain-stream or lowlandstream subbasins. Racehorse Creek subbasin is an example of a mountain-stream subbasin, whereas Fishtrap Creek subbasin is an example of a lowland-stream subbasin. Mountainstream subbasins typically are at high elevations, receive large amounts of precipitation, have surficial geology that is dominated by bedrock, and have a high percentage of land cover that is forested. Lowland-stream subbasins are closer to sea level, receive moderate precipitation, have surficial geology dominated by glacial and river sediments, and have a high percentage of land cover that is agricultural or urbanized. Mountain-stream subbasins are more likely to have snowmelt as a seasonal component of streamflow, and lowland-stream subbasins are more likely to have streamflow diverted for irrigation use or regulated for flood control. 


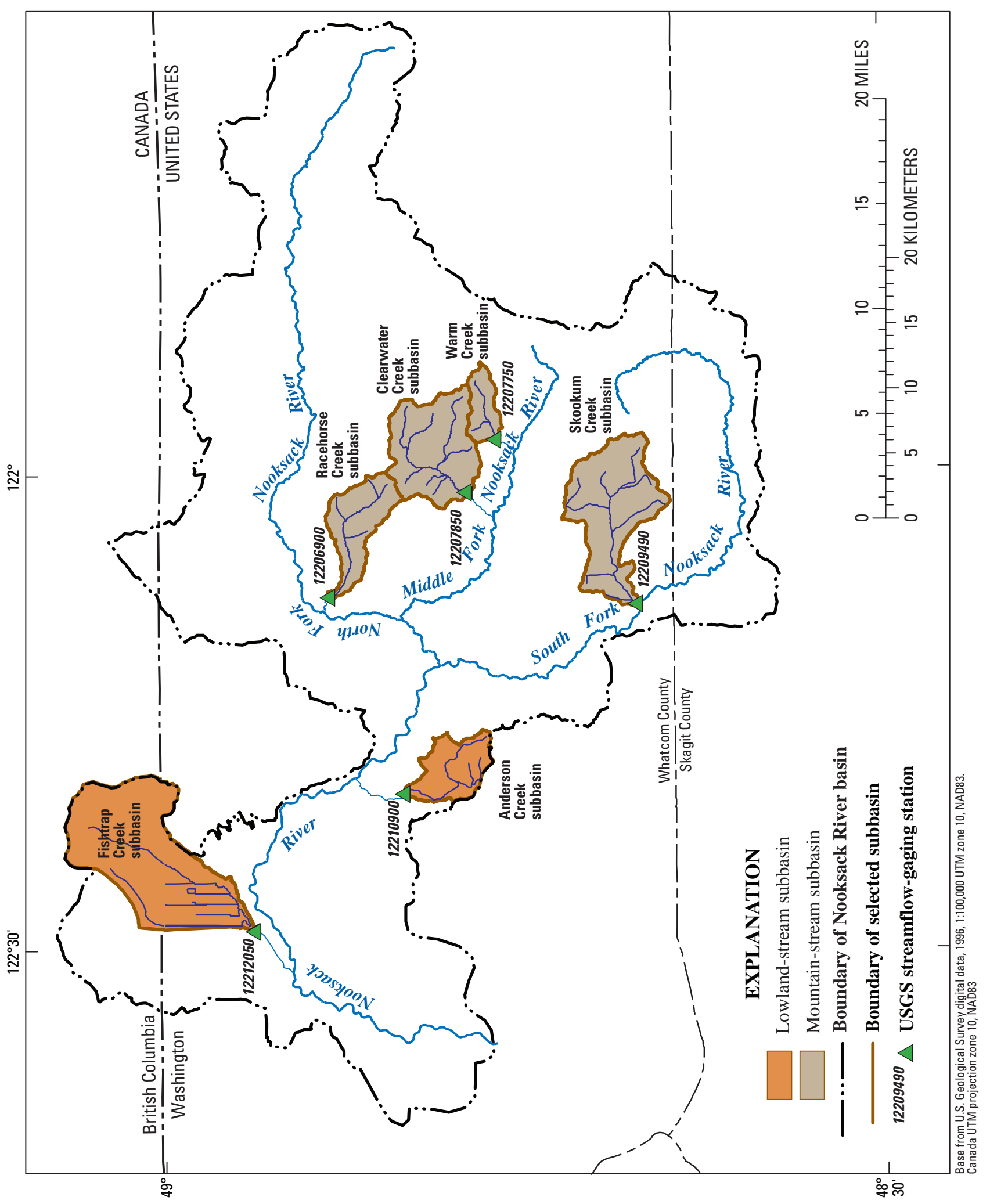




\section{Racehorse Creek}

The Racehorse Creek subbasin is about $11 \mathrm{mi}^{2}$ in size, and is located in the northeastern part of the Nooksack River basin on the northern slope of Slide Mountain in the North Fork Nooksack River basin. This mountainstream subbasin is carved through a mantle of glacial sediments and into bedrock composed of massive sandstone, conglomerate, and shale (Easterbrook and others, 2007). The subbasin has a history of landslide occurrence and is in a part of the Nooksack River basin that remains seismically active (Linneman and others, 2007). The subbasin is predominantly forested, and interspersed with areas of clear-cutting and logging roads. Most recently, the subbasin was affected by a landslide that occurred on January 7, 2009, during a period of intense rainfall. The material from this failure temporarily dammed the flow on Racehorse Creek (which already had large flows due to heavy rains) about 1 mi upstream of the gaging station, and after giving way caused an outburst flood downstream that significantly modified the stream channel in the lower part of the subbasin (fig. 4).

Racehorse Creek is a low-order stream that drains into the North Fork of the Nooksack River about $4 \mathrm{mi}$ upstream of the confluence of the Middle and North Fork Nooksack Rivers. The main channel is about $7 \mathrm{mi}$ long and runs westward from Slide Mountain at an elevation of about $4,000 \mathrm{ft}$ to its confluence with the North Fork Nooksack River at an elevation of about $400 \mathrm{ft}$. The USGS streamflow-gaging station (12206900) is $0.7 \mathrm{mi}$ upstream of the mouth of the creek and just downstream of a single-span bridge used for logging traffic. At flows less than about $20 \mathrm{ft}^{3} / \mathrm{s}$, the stage of the stream is controlled by a series of gravel/cobble bars, and at higher flows (greater than about $200 \mathrm{ft}^{3} / \mathrm{s}$ ), the stage is controlled by channel geometry and slope. The bankfull width of the channel (post-January 2009 flood) is about $75 \mathrm{ft}$ in the reach

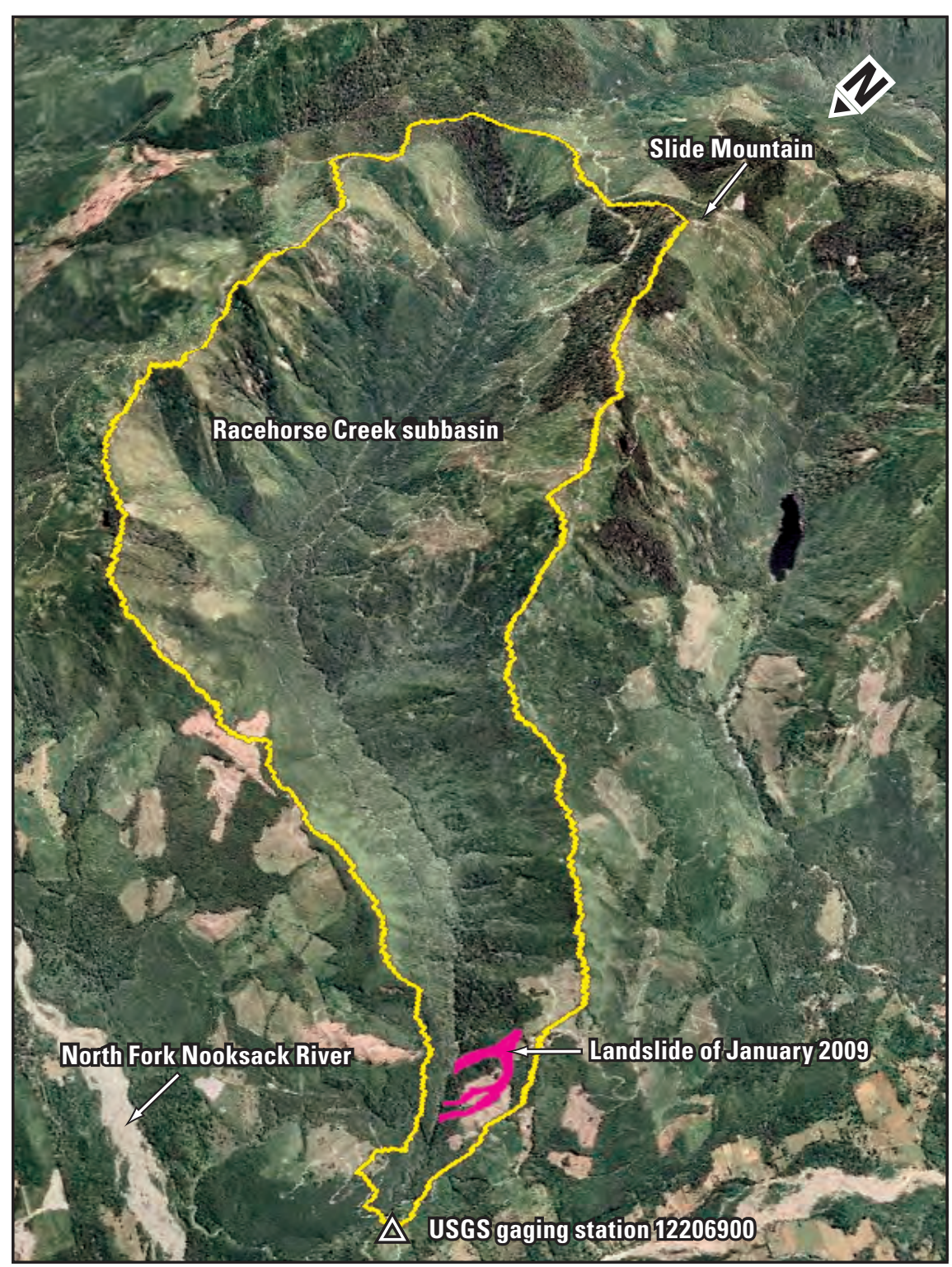

USDA National Agricultural Imagery Program (NAIP) 2006, UTM zone 10 NAD83

Figure 4. Oblique view and delineation of the Racehorse Creek subbasin with the January 2009 landslide area, Nooksack River basin, Washington. just downstream of the gaging station and the top of bank elevations are about $6.0 \mathrm{ft}$ above the gage datum (a reference datum for measuring river stage only). The reach is fairly uniform in channel shape but has been significantly altered by the January 2009 flood event, which both widened the channel and armored its banks with large woody debris (fig. 5). 

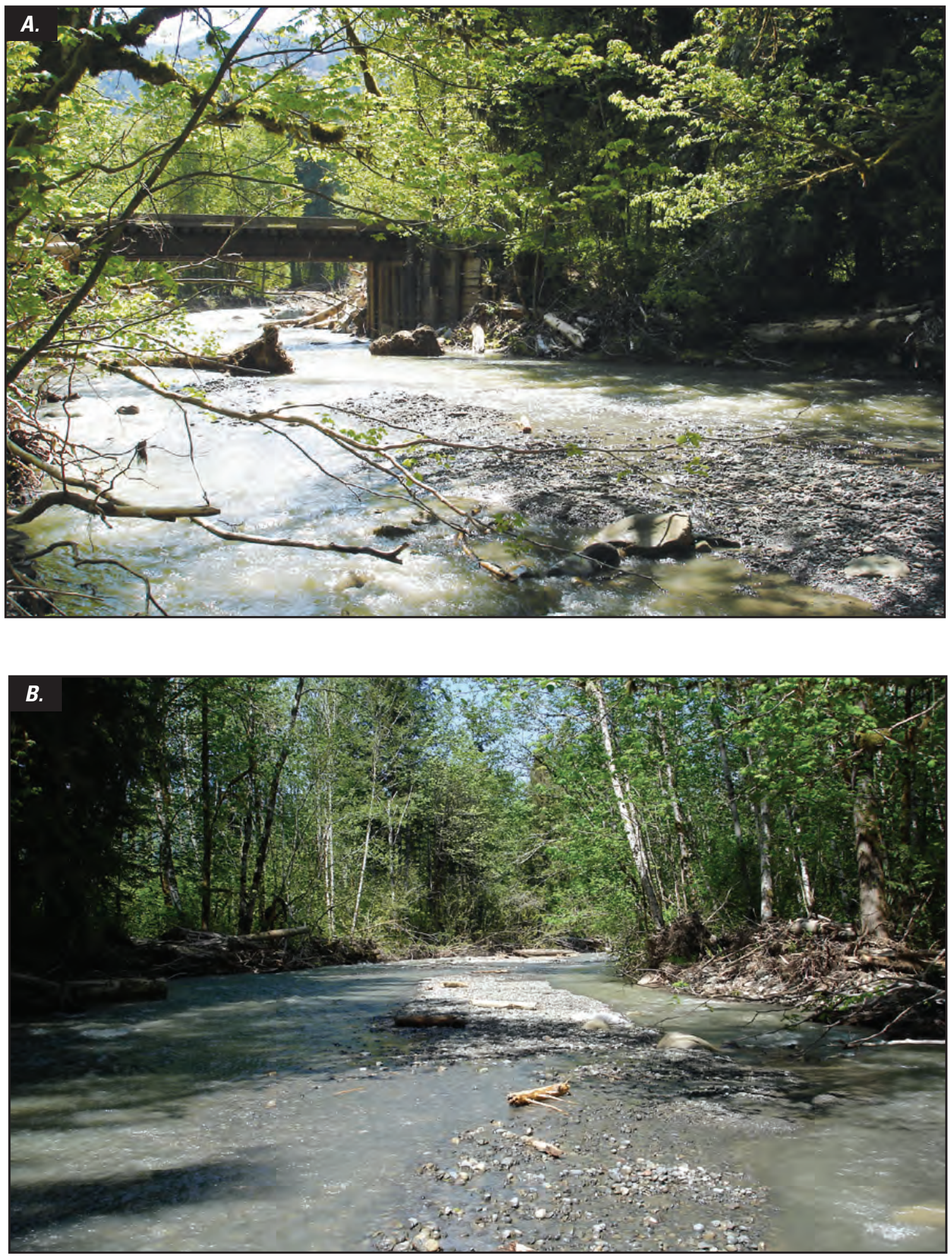

Figure 5. View looking upstream $(A)$ and downstream $(B)$ from the U.S. Geological Survey streamflow-gaging station on Racehorse Creek at North Fork Road, near Kendall, Washington (12206900). Photographs taken by Christopher Curran, U.S. Geological Survey, May 2009. 


\section{Warm Creek}

The Warm Creek subbasin is about $4 \mathrm{mi}^{2}$ in size, and located in the eastern part of the Nooksack River basin on the western edge of Mount Baker in the Middle Fork Nooksack River basin. The surficial geology in the lower subbasin is predominantly thin layers of colluvial and alpine glacial deposits overlying bedrock of sedimentary and igneous origin, the latter of which is exposed in the uppermost parts of the subbasin. This mountain-stream subbasin is predominantly forested with no known logging activity, and in the uppermost areas (above 6,000 ft elevation) contains some amount of snow throughout most of the year (fig. 6).

Warm Creek is a small low-order stream that drains into the Middle Fork of the Nooksack River about 13 mi upstream of the confluence of the Middle and North Fork Nooksack Rivers. The main channel is about $3 \mathrm{mi}$ long and runs westward from an elevation of about 5,000 ft to its confluence with the Middle Fork Nooksack River at an elevation of about $1,500 \mathrm{ft}$. The USGS streamflow gaging station (12207750) is $1 \mathrm{mi}$ upstream of the mouth of the creek. At flows less than about $50 \mathrm{ft}^{3} / \mathrm{s}$, the stage of the stream is controlled by a series of small boulders that span the channel, and at flows greater than about $70 \mathrm{ft}^{3} / \mathrm{s}$, the stage is controlled by channel geometry and slope (fig. 7). The bankfull width of the channel is estimated to be $40 \mathrm{ft}$ in the reach just upstream of the gaging station and the top of bank elevations are estimated at about $4.0 \mathrm{ft}$ above the gage datum. Access to the gaging station has been difficult due to snow accumulation in the winter, and most recently the only access road to the gaging station was washed out about $6 \mathrm{mi}$ from the gaging station. It is likely that the latter took place as a result of heavy rains that occurred in the region in January 2009.

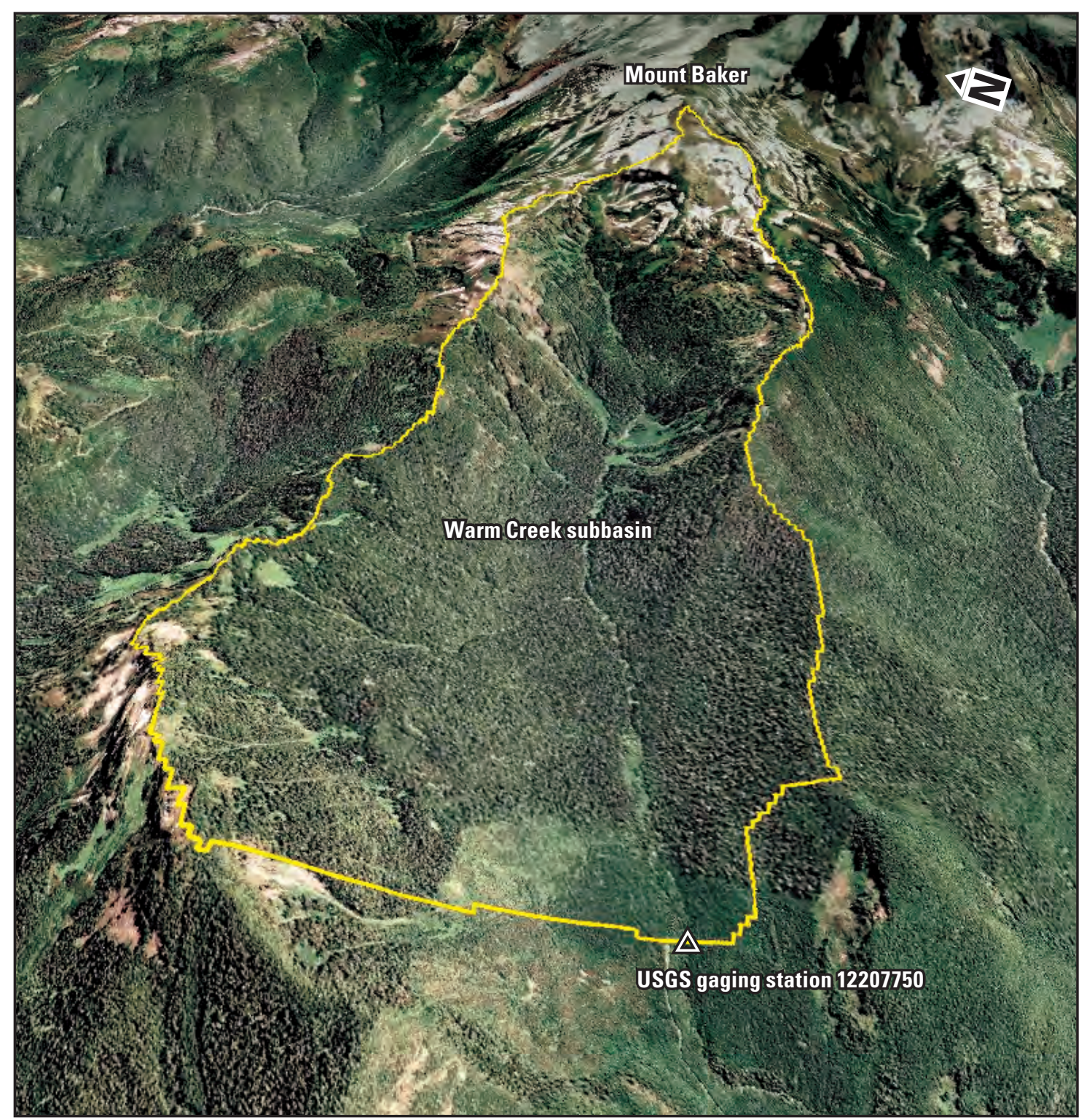

USDA National Agricultural Imagery Program (NAIP) 2006, UTM zone 10 NAD83
Figure 6. Oblique view and delineation of the Warm Creek subbasin, Nooksack River basin, Washington. 

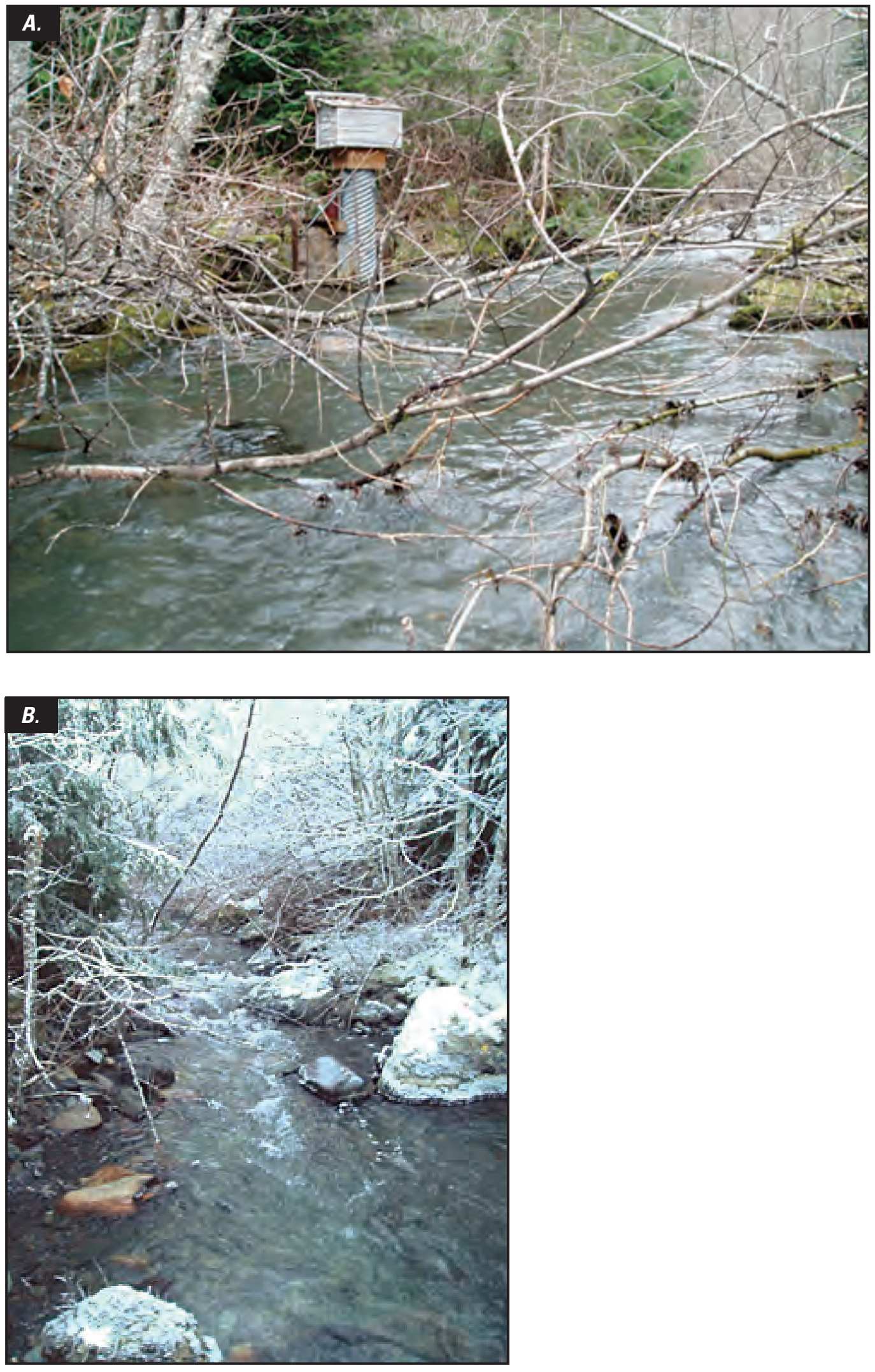

Figure 7. View looking upstream $(A)$ and downstream $(B)$ from the U.S. Geological Survey streamflowgaging station on Warm Creek near Welcome, Washington (12207750). Photographs taken by Jeffrey Paulat, U.S. Geological Survey, (A) November 2008; (B) January 2009. 


\section{Clearwater Creek}

The Clearwater Creek subbasin is about $19 \mathrm{mi}^{2}$ in size, and located in the eastern part of the Nooksack River basin, adjacent to the Warm Creek subbasin, and also in the Middle Fork Nooksack River basin. The surficial geology in the subbasin is predominantly thin layers of colluvial and glacial deposits overlying bedrock of sedimentary and igneous origin. This is a mountain-stream subbasin that is predominantly forested and interspersed with large clear-cut areas from commercial logging (fig. 8).

Clearwater Creek is a second-order stream that drains into the Middle Fork of the Nooksack River about $9 \mathrm{mi}$ upstream of the confluence of the Middle and North Fork Nooksack Rivers. The main channel is about $6 \mathrm{mi}$ long and runs generally west and southwest from an elevation of about 4,000 ft to its confluence with the Middle Fork Nooksack River at an elevation of about 1,100 ft. The USGS streamflowgaging station (12207850) is about 1.8 mi upstream of the mouth of the creek. At flows less than about $30 \mathrm{ft}^{3} / \mathrm{s}$, the stage of the stream is controlled by an irregular but smooth bedrock surface that spans the channel (fig. 9A). At medium flows $\left(30-100 \mathrm{ft}^{3} / \mathrm{s}\right)$, the stage is controlled by an irregular series of large boulders downstream of the gaging station, and at flows greater than about $200 \mathrm{ft}^{3} / \mathrm{s}$, the stage is controlled largely by channel geometry and slope (fig. 9B). The downstream left bank of the channel is a fairly steep bedrock face, whereas the downstream right bank is terraced over deposits of colluvial sand and gravel. The right bank has large cedar trees and massive boulders that constrict high flows and accumulate large woody debris. The bankfull width of the channel is about $65 \mathrm{ft}$ near the gaging station and high-water marks on the right bank, deposited during the January 2009 peak, were surveyed at 8.9 and $9.2 \mathrm{ft}$ above gage datum on May 21, 2009. In

November 2007, the gaging station was damaged during high flows caused by intense precipitation in the region; the gaging station was not restored fully until July 2008.

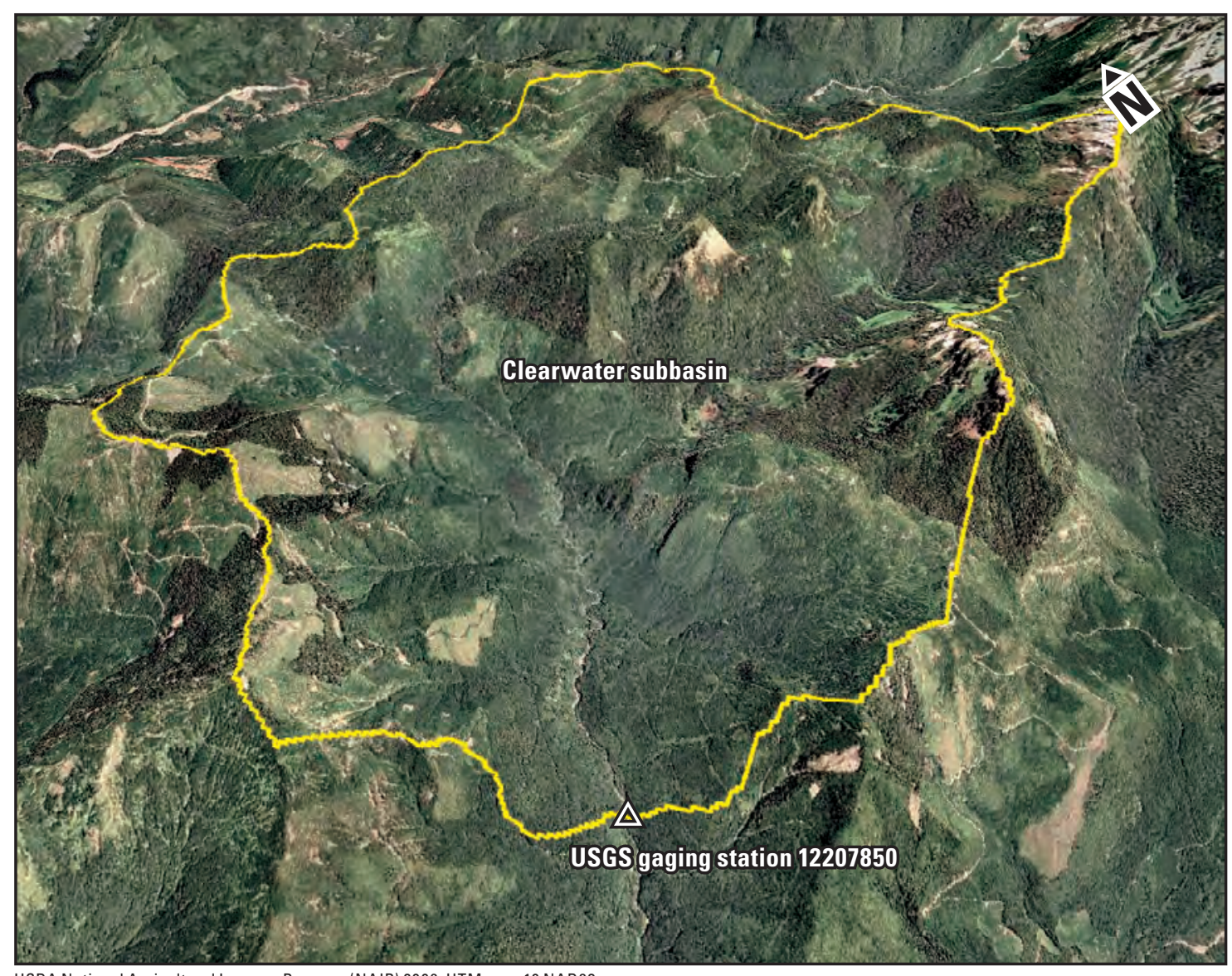

USDA National Agricultural Imagery Program (NAIP) 2006, UTM zone 10 NAD83

Figure 8. Oblique view and delineation of the Clearwater Creek subbasin, Nooksack River basin, Washington. 

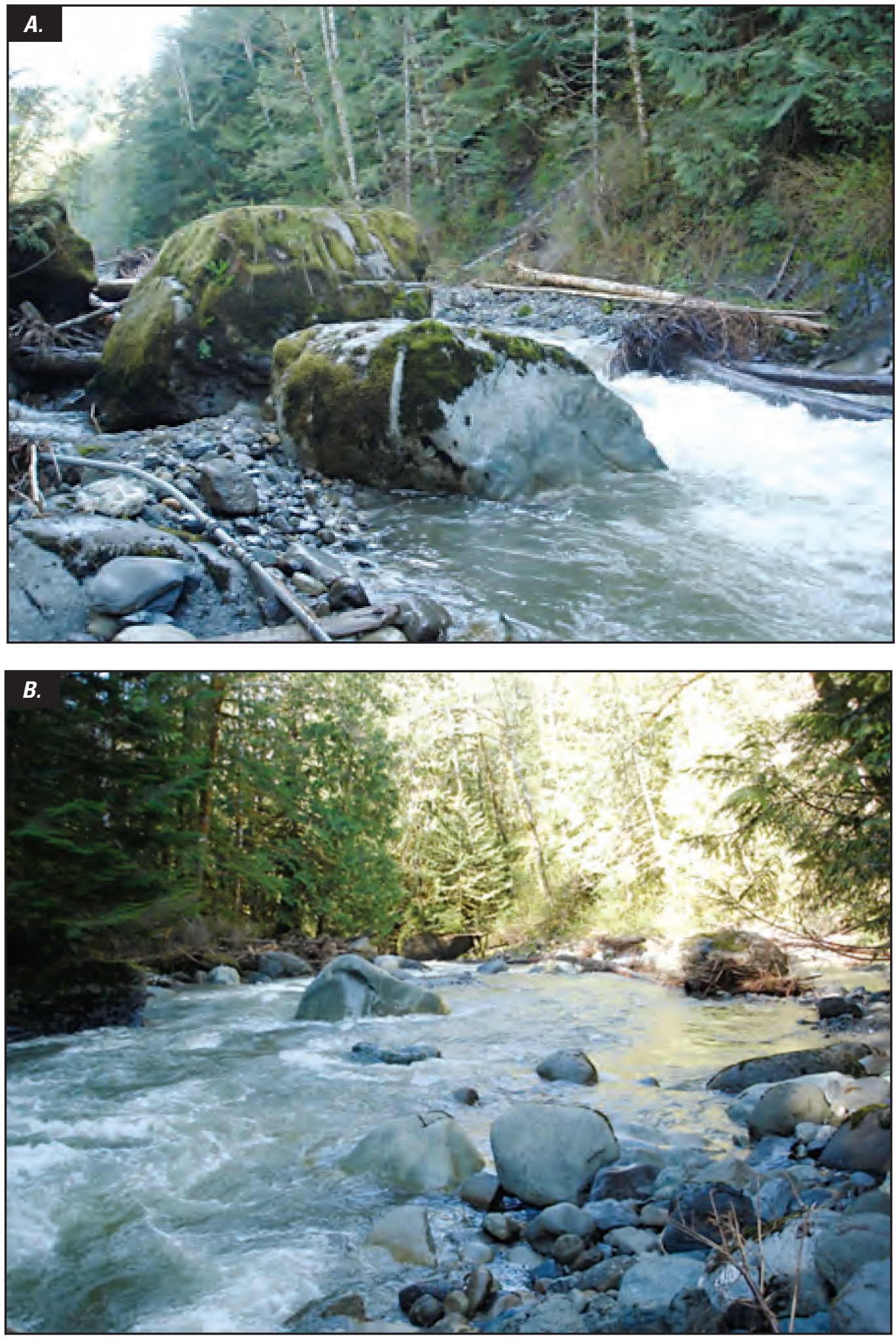

Figure 9. View looking upstream $(A)$ and downstream $(B)$ from the U.S. Geological Survey streamflow-gaging station on Clear Water Creek near Welcome, Washington (12207850). Photographs taken by Christopher Curran, U.S. Geological Survey, May 2009. 


\section{Skookum Creek}

The Skookum Creek subbasin is about $23 \mathrm{mi}^{2}$ in size, and located in the southern part of the Nooksack River basin. It extends southward from the southern flank of Twin Sisters Mountain to the South Fork Nooksack River basin. The surficial geology in the lower subbasin is predominantly thin layers of colluvial and alpine glacial deposits that overlie bedrock of sedimentary and igneous origin. The uppermost part of the basin is exposed igneous-intrusive rock that forms the jagged peaks of Twin Sisters Mountain. This mountain-stream subbasin is predominantly forested although interspersed with large clearcuts and a system of logging roads. The uppermost areas of the basin include the southern peak of Twin Sisters Mountain (about 7,000 ft elevation) and contains snow throughout most of the year (fig. 10).

Skookum Creek is a large secondorder stream that drains into the South Fork of the Nooksack River about 14 mi upstream of the confluence of the Middle and North Fork Nooksack Rivers. The main channel is about $9 \mathrm{mi}$ long and runs southward from an elevation of about 5,000 ft at the flank of Twin Sisters Mountain to its confluence with the South Fork Nooksack River at an elevation of about $400 \mathrm{ft}$. The USGS streamflow-gaging station (12209490) is $0.3 \mathrm{mi}$ upstream of the mouth of the creek. Near the gaging station, the creek is confined by bedrock on both banks and runs fairly straight for about $300 \mathrm{ft}$. At medium and low flows (less than about $300 \mathrm{ft}^{3} / \mathrm{s}$ ), the stage of the stream is

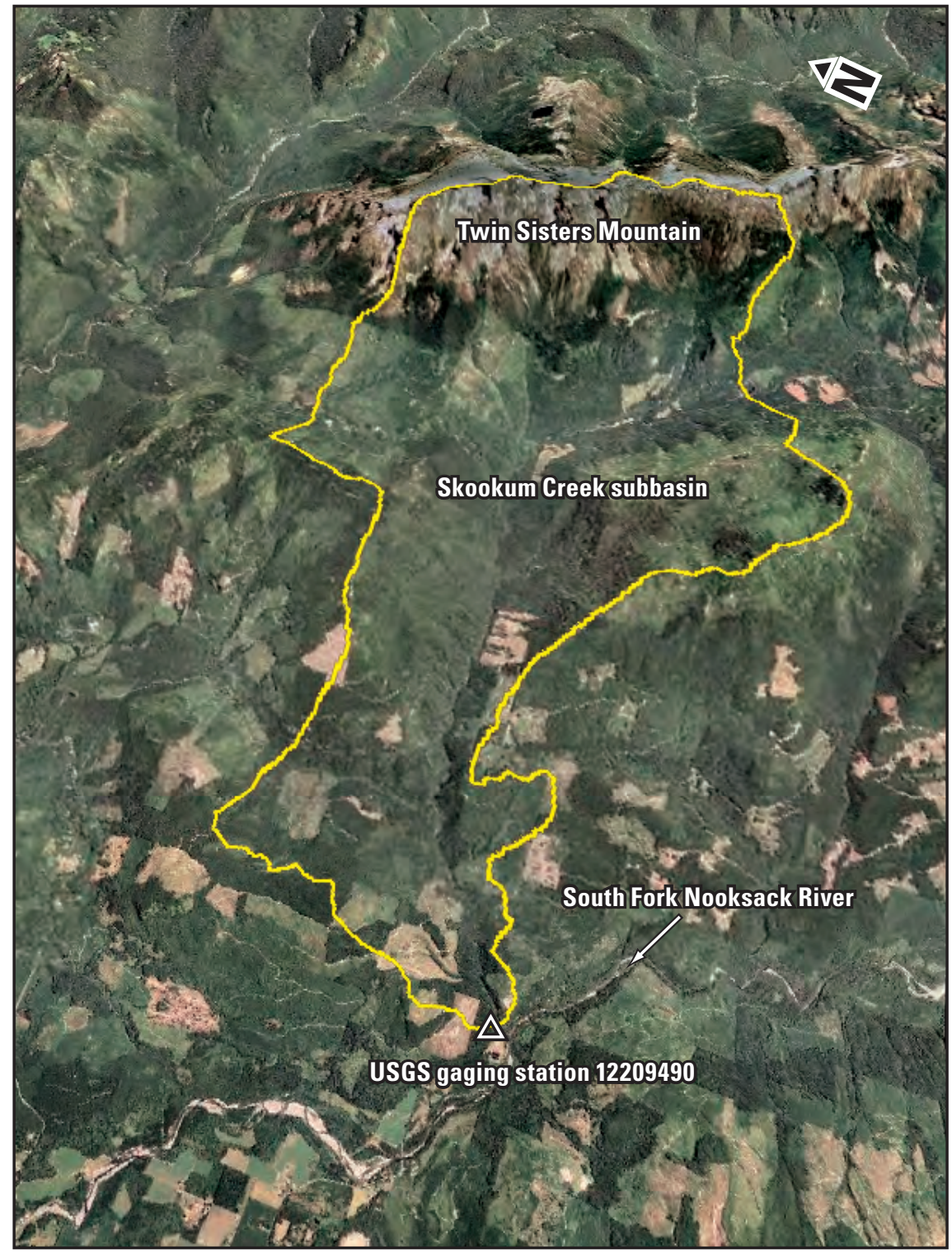

USDA National Agricultural Imagery Program (NAIP) 2006, UTM zone 10 NAD83

Figure 10. Oblique view and delineation of the Skookum Creek subbasin, Nooksack River basin, Washington. controlled by bedrock and a series of medium boulders, at higher flows (greater than about $400 \mathrm{ft}^{3} / \mathrm{s}$ ), the stage is controlled by channel geometry and slope (fig. 11). The width of the channel is about $55 \mathrm{ft}$ at the gaging station with no clearly defined top of bank. Streamflow data from this station is used by the National Weather Service for calibrating a hydrologic model for the South Fork Nooksack River (Brent Bower, National Weather Service, written commun., July 7, 2009). 

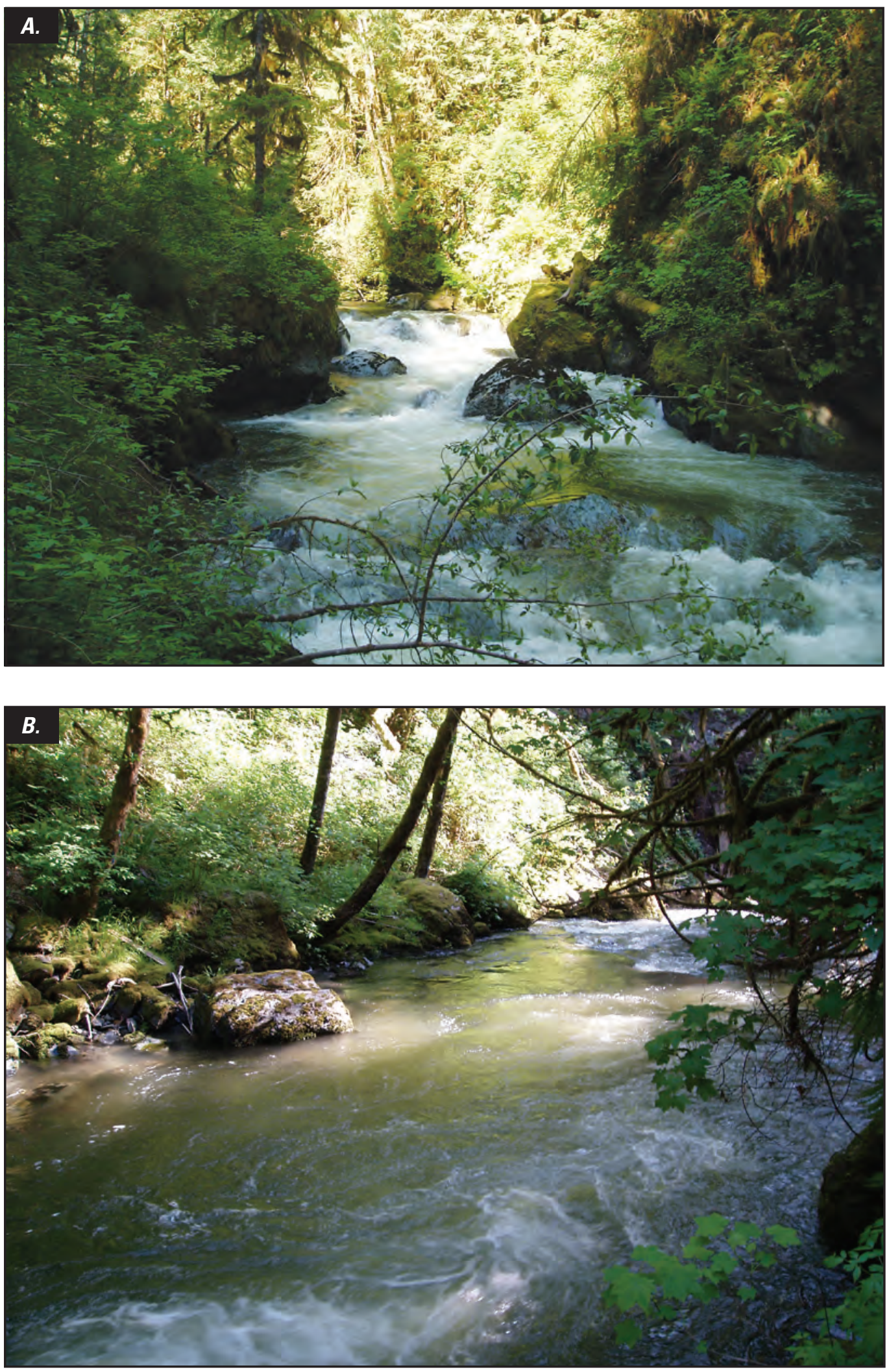

Figure 11. View looking upstream $(A)$ and downstream $(B)$ from the U.S. Geological Survey streamflow-gaging station on Skookum Creek near Wickersham, Washington (12209490). Photographs taken by Jeffrey Paulat, U.S. Geological Survey, June 2009. 


\section{Anderson Creek}

The Anderson Creek subbasin is about $9 \mathrm{mi}^{2}$ in size, and located in the transition between the Puget Lowland and the foothills of the Cascade Range in the Nooksack River basin. The surficial geology in this lowland-stream subbasin is coarse- to fine-grained glacial deposits in the lower half of the subbasin, with thin layers of glacial sediments mantling sedimentary bedrock at high elevations. The subbasin is a mix of forested land, agricultural land, and residential areas (fig. 12).

Anderson Creek is a low-order stream that drains into the mainstem of the Nooksack River about 8 mi downstream of the confluence of the South Fork and mainstem Nooksack Rivers. The stream channel is about $3 \mathrm{mi}$ long and runs northward from an elevation of about $3,000 \mathrm{ft}$ to its confluence with the Nooksack River at an elevation of about $200 \mathrm{ft}$.
The USGS streamflow-gaging station (12210900) is $3 \mathrm{mi}$ upstream of the mouth of the creek. Just upstream of the gaging station, the stream channel is confined by rip-rap on both banks that support a single-span overpass. A drainage ditch about $0.2 \mathrm{mi}$ long runs parallel to the roadway and enters the main channel just upstream of the overpass. At flows less than about $20 \mathrm{ft}^{3} / \mathrm{s}$, the stage of the stream is controlled by gravel bars, at higher flows (greater than $100 \mathrm{ft}^{3} / \mathrm{s}$ ), the stage is controlled by channel geometry and slope (fig. 13). Channel banks are heavily vegetated with brush and overhanging trees. In late summer, streamflow in the creek has been observed to become so low that it cannot be measured, and is recorded as effectively zero flow (Jeffrey Paulat, U.S. Geological Survey, oral commun., 2009). The bankfull width of the channel is about $48 \mathrm{ft}$ near the gaging station and high-water marks on both banks, deposited during the January 2009 peak, were surveyed at 11.4 and $11.0 \mathrm{ft}$ above gage datum on May 21, 2009.

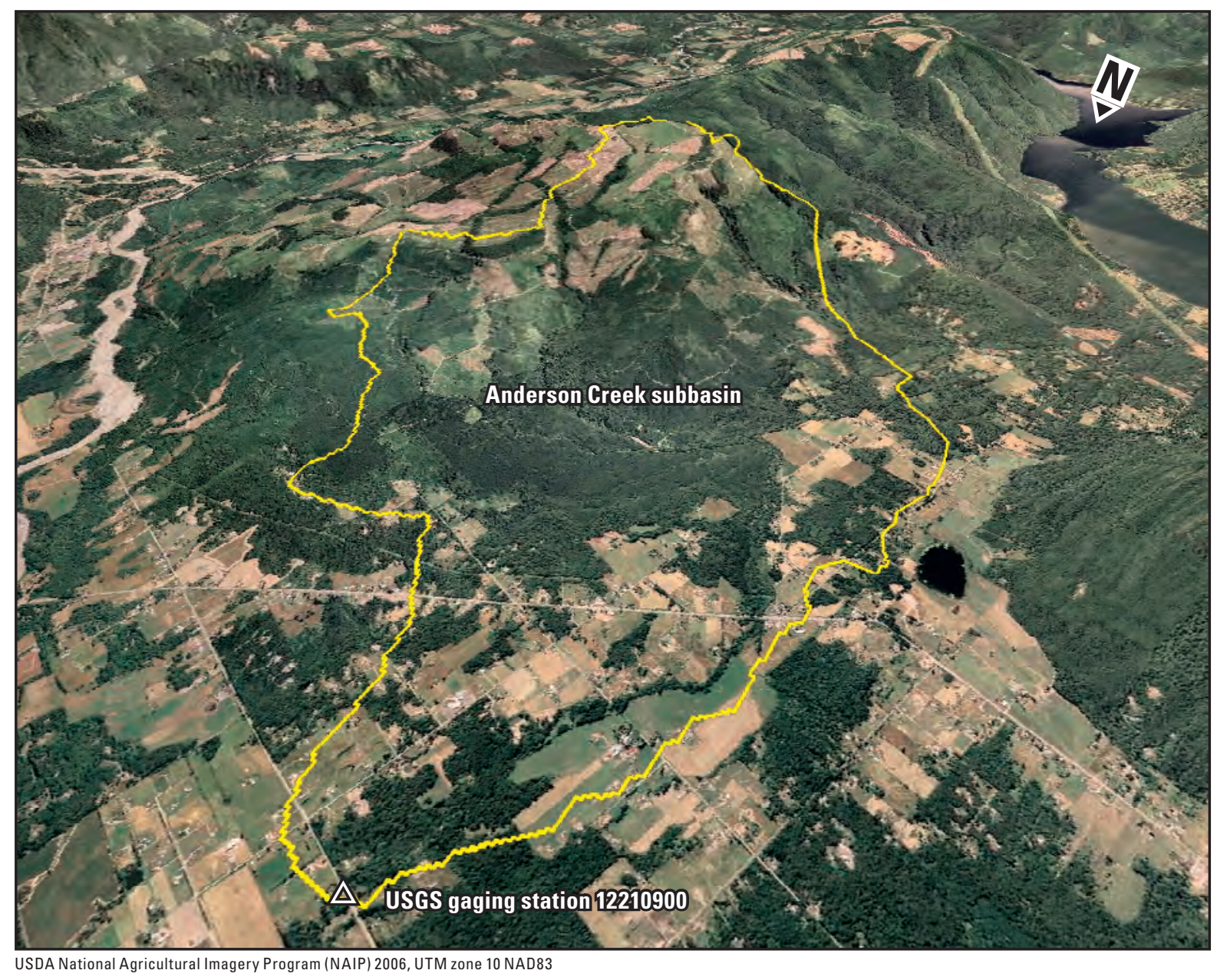

Figure 12. Oblique view and delineation of the Anderson Creek subbasin, Nooksack River basin, Washington. 

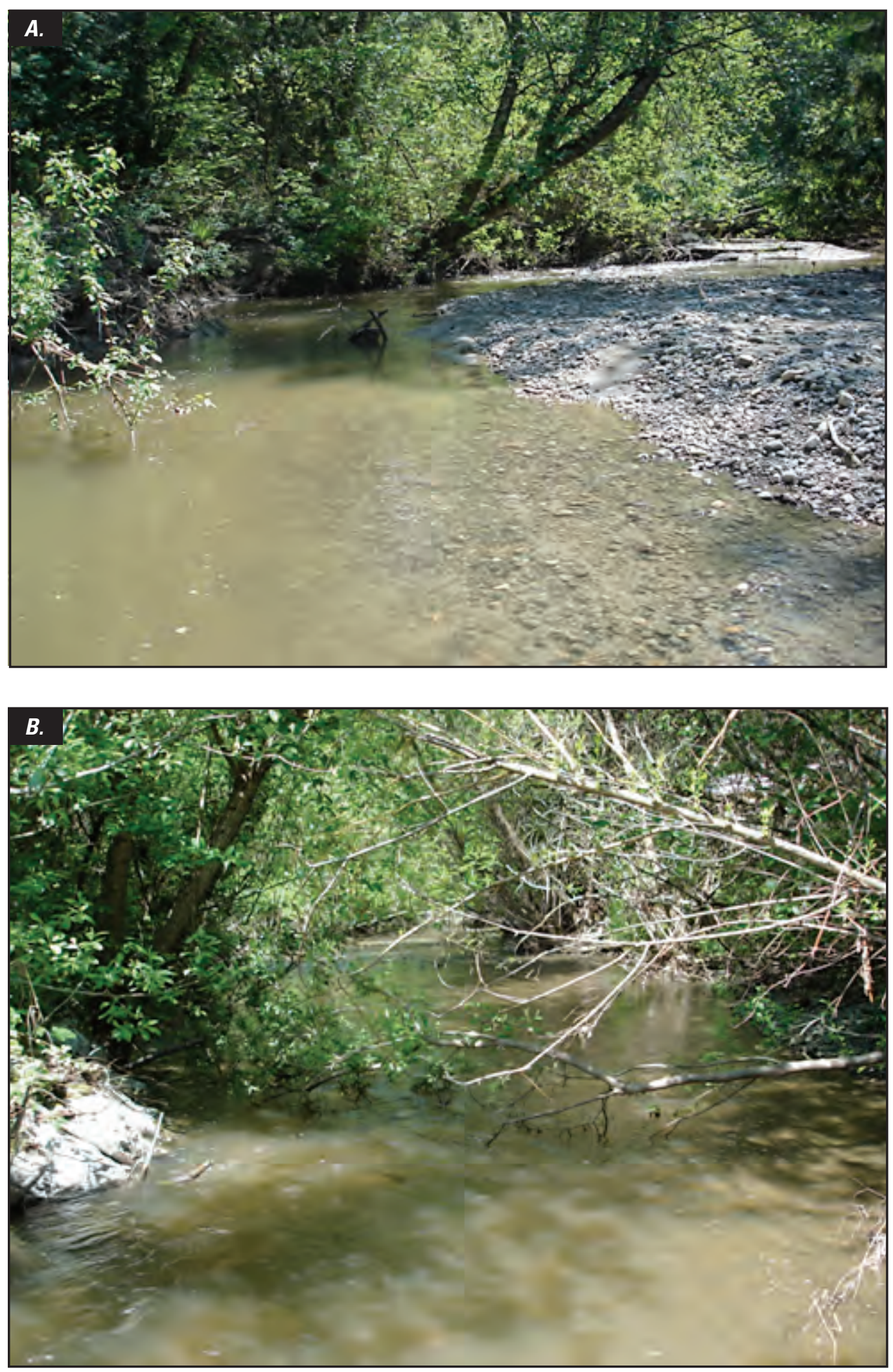

Figure 13. View looking upstream $(A)$ and downstream $(B)$ from the U.S. Geological Survey streamflow-gaging station on Anderson Creek near Goshen, Washington (12210900). Photographs taken by Christopher Curran, U.S. Geological Survey, May 2009. 


\section{Fishtrap Creek}

The Fishtrap Creek subbasin is about $37 \mathrm{mi}^{2}$ in size (26 $\mathrm{mi}^{2}$ of which are in Canada) and located in the Puget Lowland in the Nooksack River basin. The surficial geology in this lowland-stream subbasin is coarse- to fine-grained glacial deposits and coarse-grained alluvial deposits. The subbasin is primarily agricultural land and residential areas (fig. 14).

Fishtrap Creek is a second-order stream that enters the mainstem of the Nooksack River about $13 \mathrm{mi}$ upstream of the mouth. The stream channel is about $11 \mathrm{mi}$ long and runs southward from an elevation of about $200 \mathrm{ft}$ to its confluence with the Nooksack River at an elevation of about $30 \mathrm{ft}$. Previous investigations in the creek have found fecal bacteria and elevated nitrogen concentrations, likely from tile drains and ditches that drain agricultural fields and enter the creek
(Cox and others, 2005). The USGS streamflow-gaging station (12212050) is $3 \mathrm{mi}$ upstream of the mouth of the creek, and at the downstream end of a three-section box culvert (fig. 15A). At flows less than about $100 \mathrm{ft}^{3} / \mathrm{s}$, the stage of the stream is controlled by gravel bars, at higher flows (greater than $200 \mathrm{ft}^{3} / \mathrm{s}$ ), the stage is controlled by channel geometry and slope (fig. 15B). Channel banks are heavily vegetated with brush and overhanging trees, and a slope failure recently occurred on the downstream right bank about $80 \mathrm{ft}$ downstream of the gaging station, likely during the January 2009 flooding. The bankfull width of the channel is about $65 \mathrm{ft}$ in the cross section $50 \mathrm{ft}$ downstream of the gaging station and high-water marks on both banks, deposited during the January 2009 peak, were surveyed at 8.0 and $7.9 \mathrm{ft}$ above gage datum on May 21, 2009.

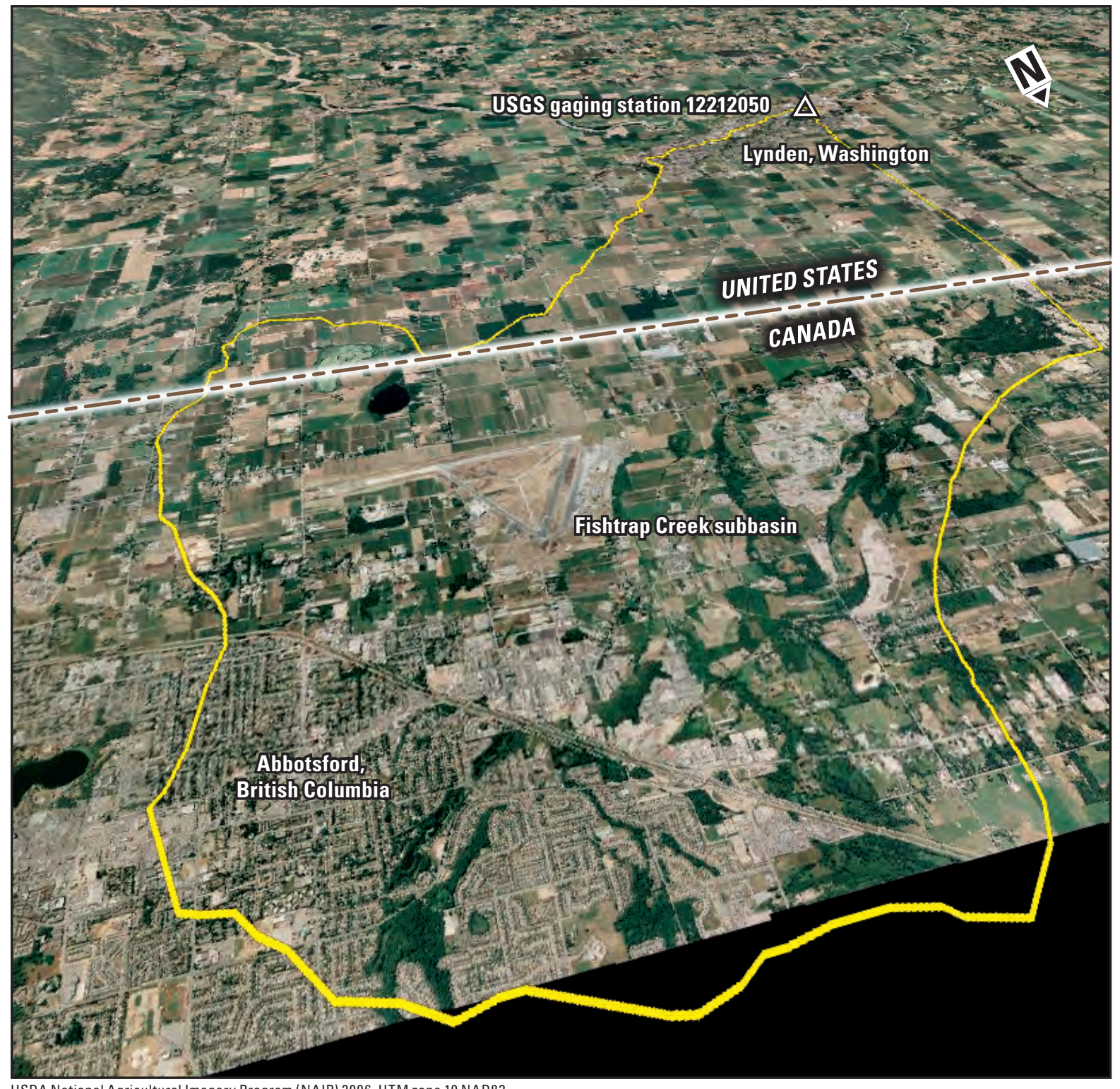

USDA National Agricultural Imagery Program (NAIP) 2006, UTM zone 10 NAD83

Figure 14. Oblique view and delineation of the Fishtrap Creek subbasin, Nooksack River basin, Washington. 

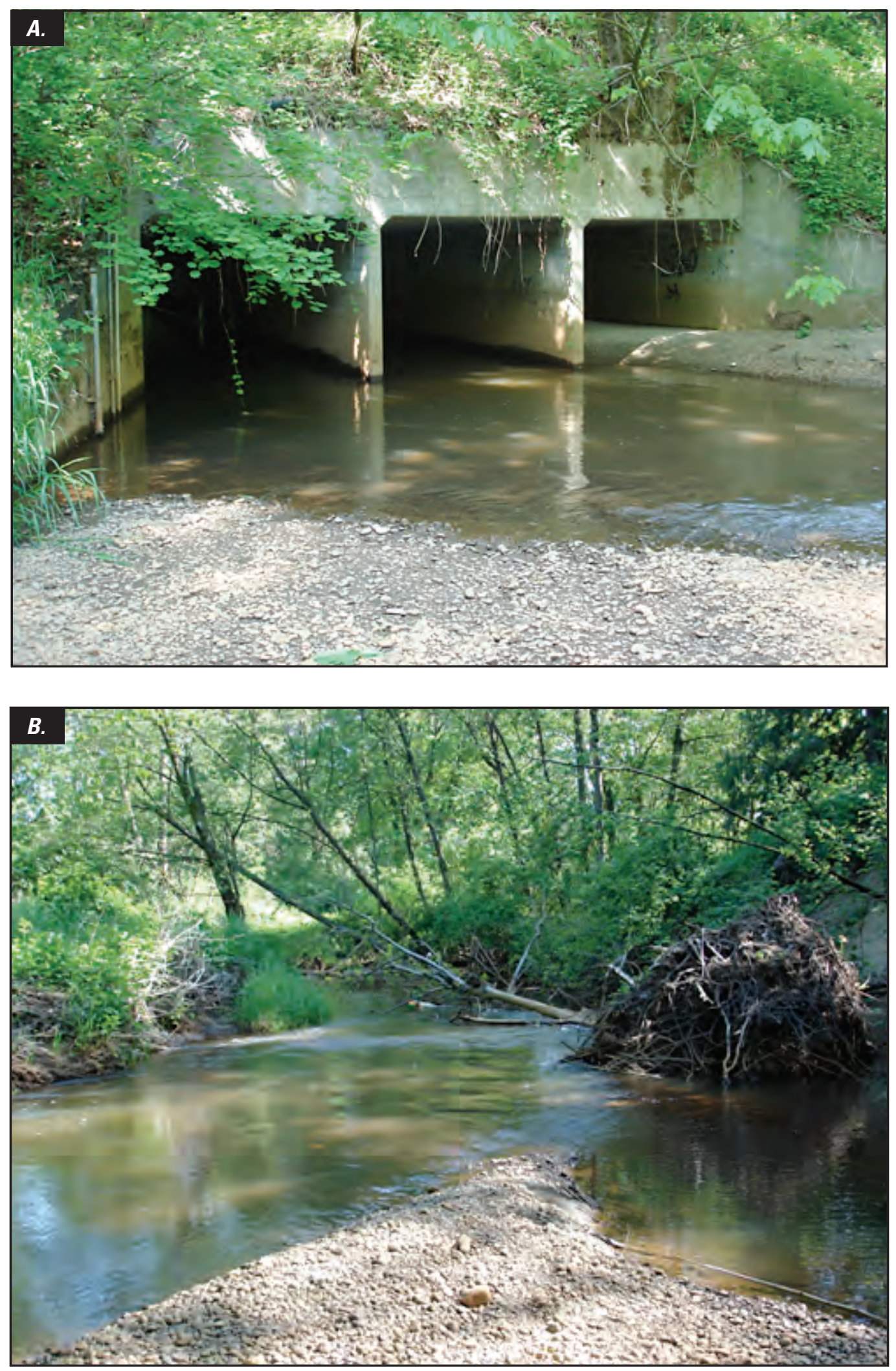

Figure 15. View looking upstream $(A)$ and downstream $(B)$ from the U.S. Geological Survey streamflow-gaging station on Fishtrap Creek near Lynden, Washington (12212050). Photographs taken by Christopher Curran, U.S. Geological Survey, May 2009. 


\section{Evaluation of Redundancy in the Streamflow- Gaging Station Network}

In addition to developing regional regression equations for low-flow frequency statistics, the Lummi Nation requested that the USGS determine whether some of the six streamflow-gaging stations were collecting redundant streamflow information and whether some of the gaging stations could be removed from the network without significant loss of information. Redundancy in this study is defined as similarity in the timing, magnitude and frequency of streamflow. Because identifying and removing redundancy in the streamflow-gaging station network is essentially optimizing the network, it is helpful to define an optimal network. An optimal streamflow-gaging station network is one that contains the fewest number of gaging stations and yet provides streamflow information that represents the spectrum of hydrologic variability in the basin, while satisfying the data needs for various present and future water-resource studies and management alternatives. Reducing redundancy in a network thus involves identifying elements of hydrologic variability (for example the magnitude, frequency, and timing of streamflow) and determining which gaging stations are essential for explaining the observed variability and which are not.

Four methods were used for considering data redundancy: hydrograph comparison, daily-value correlation, variable space, and flow-duration ratios. Each method involves some aspect of hydrologic variability that can be either qualitatively or quantitatively evaluated. The results from each method should be considered along with the intended long-term use of the data-collection network. For example, the daily-value-correlation method is useful in determining which gaging stations might provide the best estimate of daily mean streamflow in the six subbasins and possibly other subbasins of the Nooksack River basin. However, the daily-valuecorrelation method does not address whether the network is adequate for improving future regional regressions for low- or high-flow frequency statistics. Other methods such as variable space, hydrograph comparison, and possibly flow-duration ratios are better suited to determine redundancy in the network for the purpose of improving future regional regression equations for low- and high-flow frequency statistics.

\section{Hydrograph Comparison Method}

Hydrograph comparison is a method for examining the similarities and differences of streamflow patterns (the timing and magnitude of flow) between gaging stations. A hydrograph is a plot of streamflow over time at a gaging station, and hydrographs that are similar in the timing and magnitude of streamflow share a redundancy in streamflow information. Because of the difference in scale between large and small streams, hydrograph comparison usually is done with streamflow plotted on a logarithmic scale to make visual comparisons easier. Physical scaling effects between streams also can be further reduced and similarities in streamflow patterns can be more easily discerned by normalizing streamflow, by dividing daily flow at each gaging station by its subbasin drainage area (this ratio also is referred to as 'streamflow runoff'). A visual inspection of the normalized hydrographs for all six gaging stations in water year 2003 (a near-average water year) shows many similarities in the timing and relative magnitude of streamflow patterns as well as some differences (fig. 16). Although most mountain-stream gaging stations (Racehorse, Warm, Clearwater, and Skookum Creeks) have a similar runoff response to storm events during the winter and spring seasons (mid-October to mid-June), runoff patterns are different during the summer season (mid-June to mid-October) when baseflow conditions exist. For example, mountain-stream gaging stations began the 2003 winter season with similar streamflow runoff, but as summer progressed, Racehorse Creek was less sustained by baseflow and Warm Creek had high runoff due to snowmelt contributions. Streamflow runoff generally is less in lowland streams than in mountain streams, likely due to lower precipitation amounts. Of the two lowland streams, Anderson Creek is the only stream with periods of zero flow, whereas streamflow in Fishtrap Creek appears more sustained from baseflow during the summer season.

A closer inspection of streamflow hydrographs at the 15-minute time interval during the period of July 11-31, 2002 (during a wetter than average water year) shows similarities and differences in baseflow-recession characteristics between the six gaging stations (fig. 17). The slope of the baseflowrecession curve can be quantified as the baseflow-recession time constant or simply 'tau' (Eng and Milly, 2008), and has implications for groundwater recharge to streams. During lowflow periods without significant precipitation, streams with large tau exhibit a gradual decrease in streamflow indicating more contribution from groundwater recharge, whereas streams with smaller tau lack this recharge (possibly losing water to the groundwater system) and recede more quickly. The value of tau can be determined as follows (Eng and Milly, 2008):

$$
\tau=\Delta t / \ln \left(Q_{t+\Delta t} / Q_{t}\right)
$$

where

$\tau$ is the baseflow-recession constant or tau, in days;

$\Delta t$ is the number of days between streamflow measurements;

$Q_{t+\Delta t}$ is the streamflow after $\Delta t$ days, and

$Q_{t}$ is the streamflow at the beginning of $\Delta t$ days. 


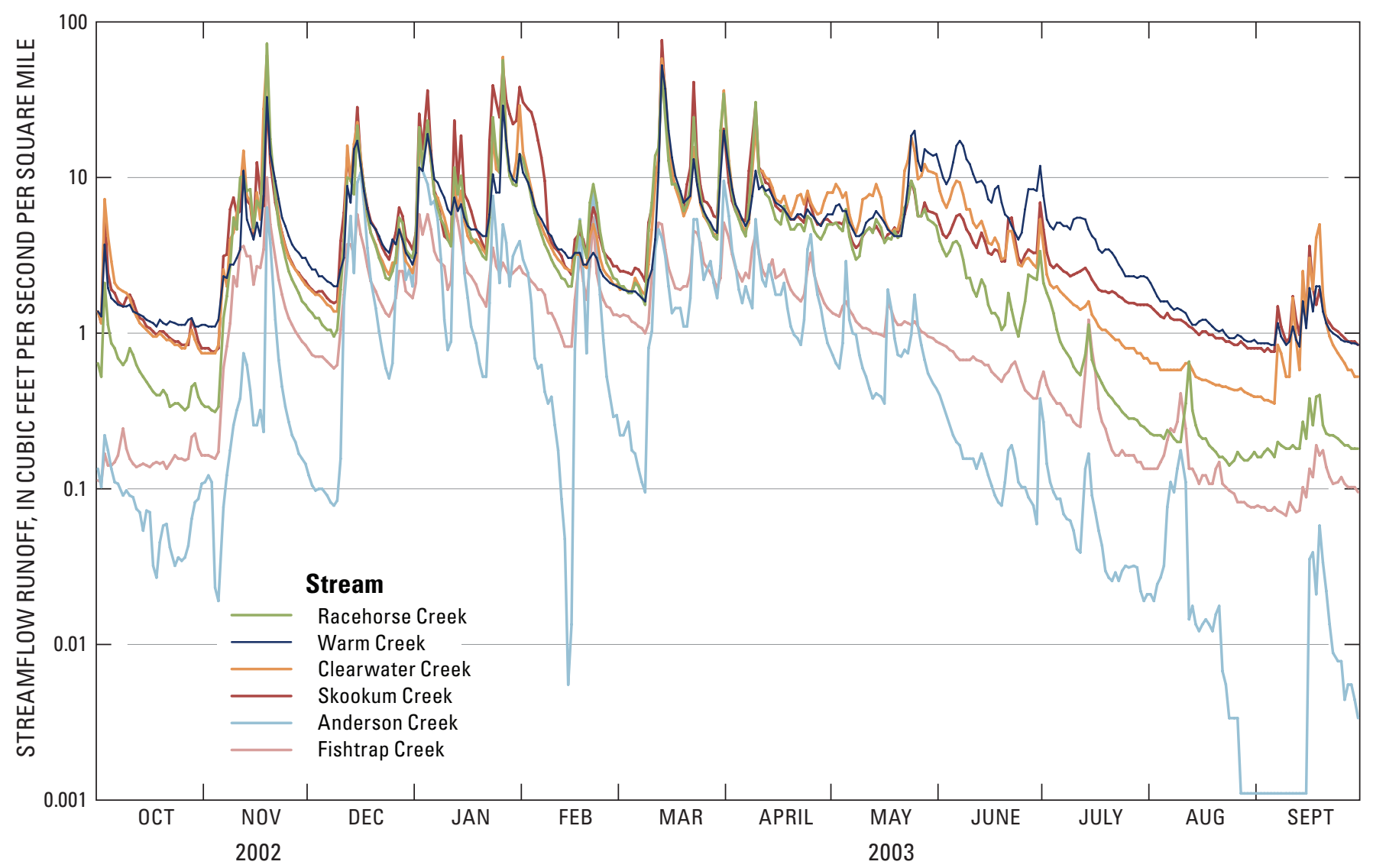

Figure 16. Daily streamflow runoff at six streamflow-gaging stations in the Racehorse, Warm, Clearwater, Skookum, Anderson, and Fishtrap Creek subbasins, Nooksack River basin, Washington and Canada, water year 2003.

Average tau values computed for all sites for the baseflow-recession period July 11-31 (fig. 17) were similar for Racehorse, Clearwater, and Anderson Creeks, whereas Skookum and Warm Creeks were more similar to each other. Fishtrap Creek had a more gradual baseflow recession than any of the other sites during this period. The diurnal pulses of streamflow at Warm, Clearwater, and Skookum Creeks were caused by snowmelt. The hydrograph for Fishtrap Creek shows a small decrease in streamflow mid-way through the period, possibly associated with water diversion upstream for irrigation.

The hydrograph comparison method suggests that a streamflow-gaging station network of two or four stations would minimize redundancy in streamflow patterns (timing, magnitude) in the six subbasins depending on the priority of peak-flow or baseflow conditions. A network prioritized for peak streamflow runoff would contain at least two stations, including a mountain-stream and lowland-stream site. A network of two stations would include Anderson Creek (12210900) or Fishtrap Creek (12212050) (lowest peak runoff), and either Skookum Creek (12209490), Clearwater Creek (12207850), Racehorse Creek (12206900), or Warm Creek (12207750) (similar peak runoff). A network with a priority for baseflows would contain four stations - Anderson Creek (12210900) (smallest tau), Fishtrap Creek (12212050) (highest tau), and either Skookum Creek (12209490) or Warm Creek (12207750) (similar tau and snowmelt processes), and either Clearwater Creek (12207850) or Racehorse Creek (12206900) (similar tau). 


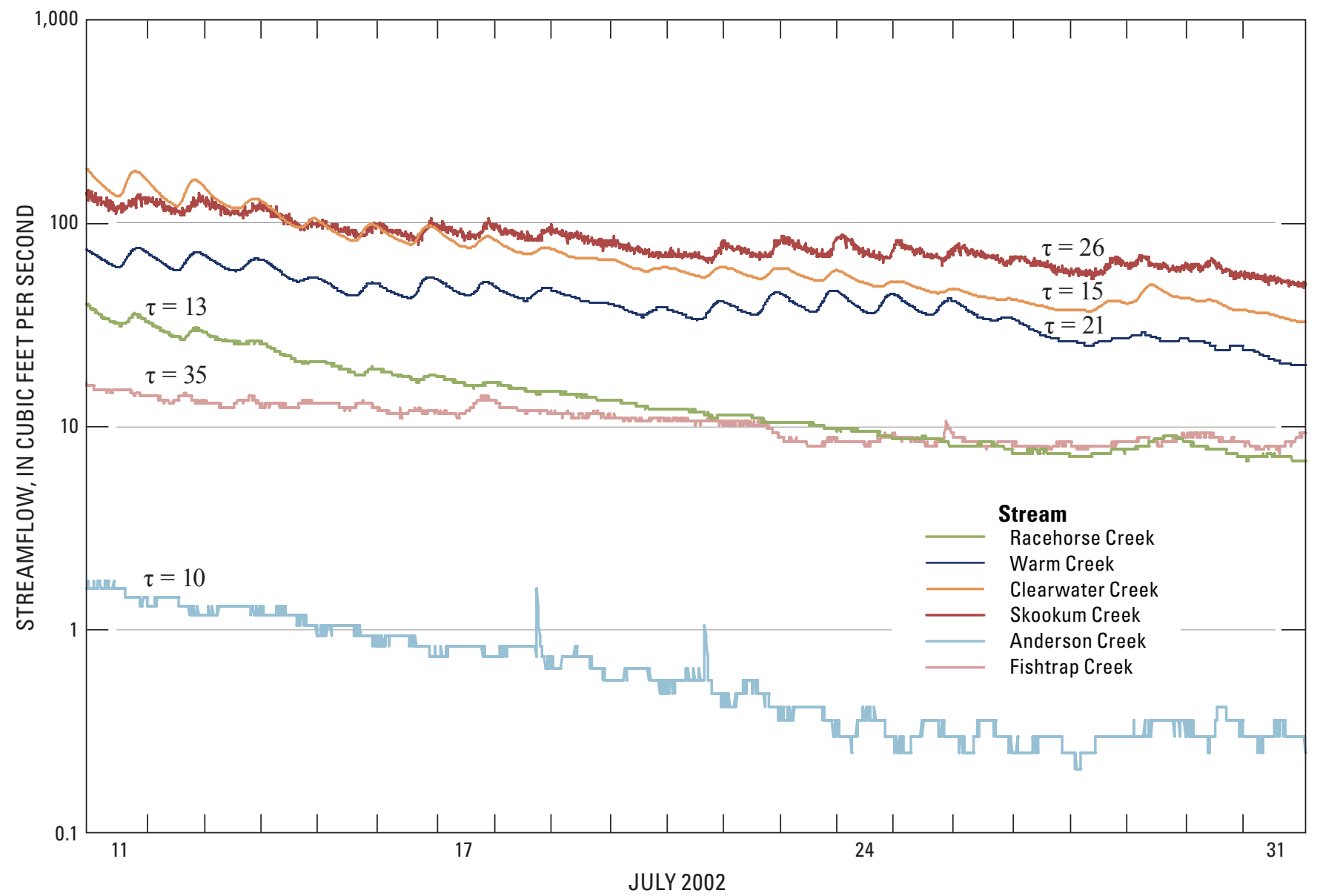

Figure 17. Fifteen-minute streamflow and average tau $(\tau)$ values during the period of July 11-31 at six gaging stations in the Racehorse, Warm, Clearwater, Skookum, Anderson, and Fishtrap Creek subbasins, Nooksack River basin, Washington and Canada. Average values for the baseflow recession time constant $(\tau)$, in days, for July 11-31, 2002.

\section{Daily-Value Correlation Method}

A more quantitative method for evaluating redundancy in the network of six gaging stations is to examine the correlation between the daily mean streamflows of all stations. A metric for correlation is Pearson's $r$, a coefficient which is the square root of the coefficient of determination, $r^{2}$. A large $r$ value between two stations indicates that daily mean streamflows at one station can be reasonably estimated as a function of daily mean streamflows at the other station. When two stations are strongly correlated, one of the two stations may be removed from the network without significant loss of information. The matrixes in figure 18 show the data plots and correlation coefficients for Linear Organic Correlation (LOC) regressions of the base e logarithms (natural logs) of daily mean streamflows for all six stations during summer (June 16-Oct. 15), winter (Oct. 16-Feb. 14), and spring (Feb. 15June 15). Equivalent regression equations that express daily mean streamflow at one station as a function of daily mean streamflow at a second station are presented in appendix A. In this study, $r$ values $\geq 0.84\left(r^{2} \geq 0.7\right)$ are considered well correlated. A summary of $r$ values (table 6) shows that good correlation among sites is more common during the winter (high flow) season (seven $r$ values $\geq 0.84$ ) than the summer (low flow) season (five $r$ values $\geq 0.84$ ) and spring (transition flows) season (five $r$ values $\geq 0.84$ ). However, the summer season has the highest average correlation for flows among the six stations (average $r=0.79$ ), compared to winter (0.78) and spring (0.40). 


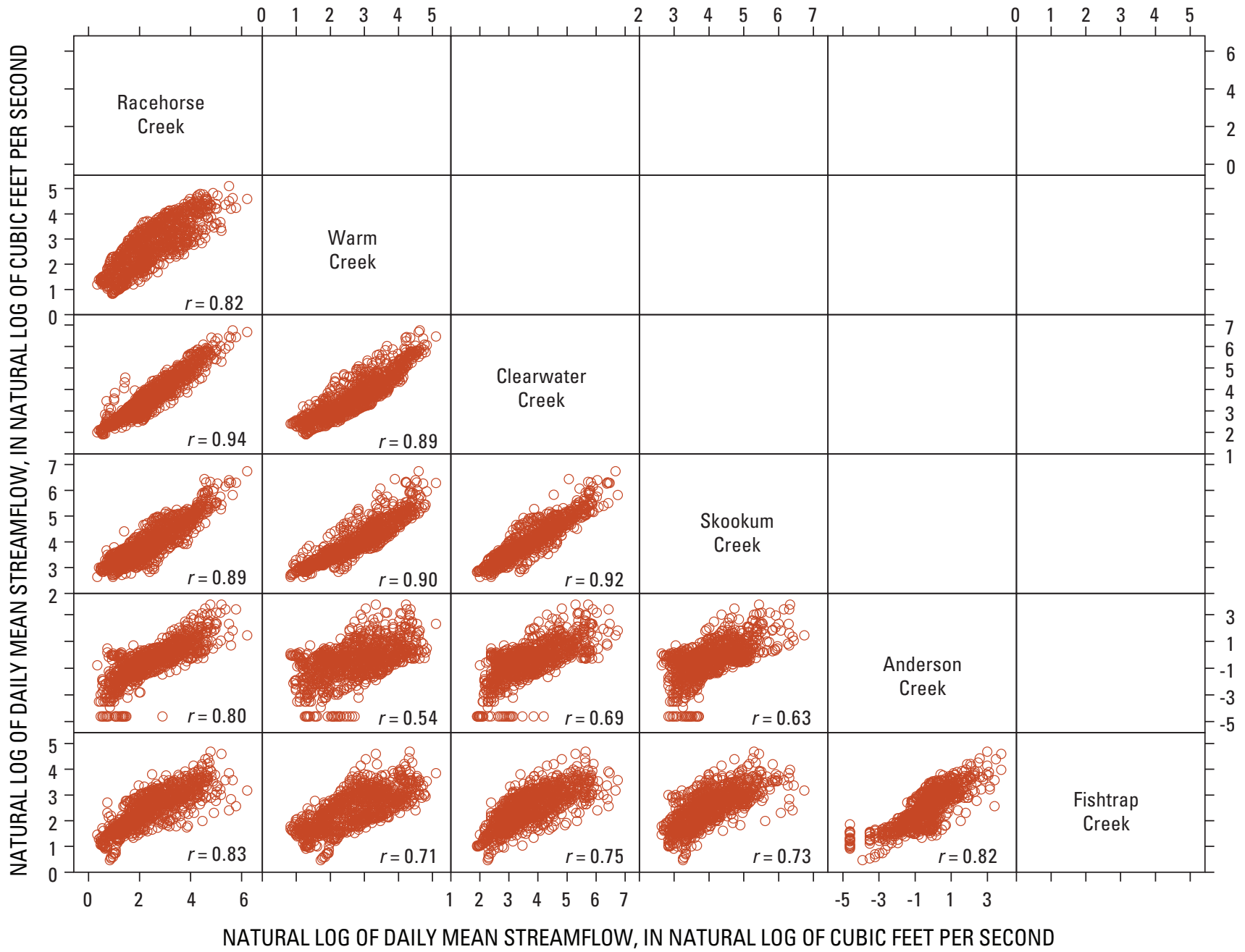

\section{A. Summer season (June 16-0ct. 15)}

Figure 18. Relation among the natural logs of daily mean streamflows during the summer, winter, and spring seasons at each of six gaging stations in the Racehorse, Warm, Clearwater, Skookum, Anderson, and Fishtrap Creek subbasins, Nooksack River basin, Washington and Canada. 


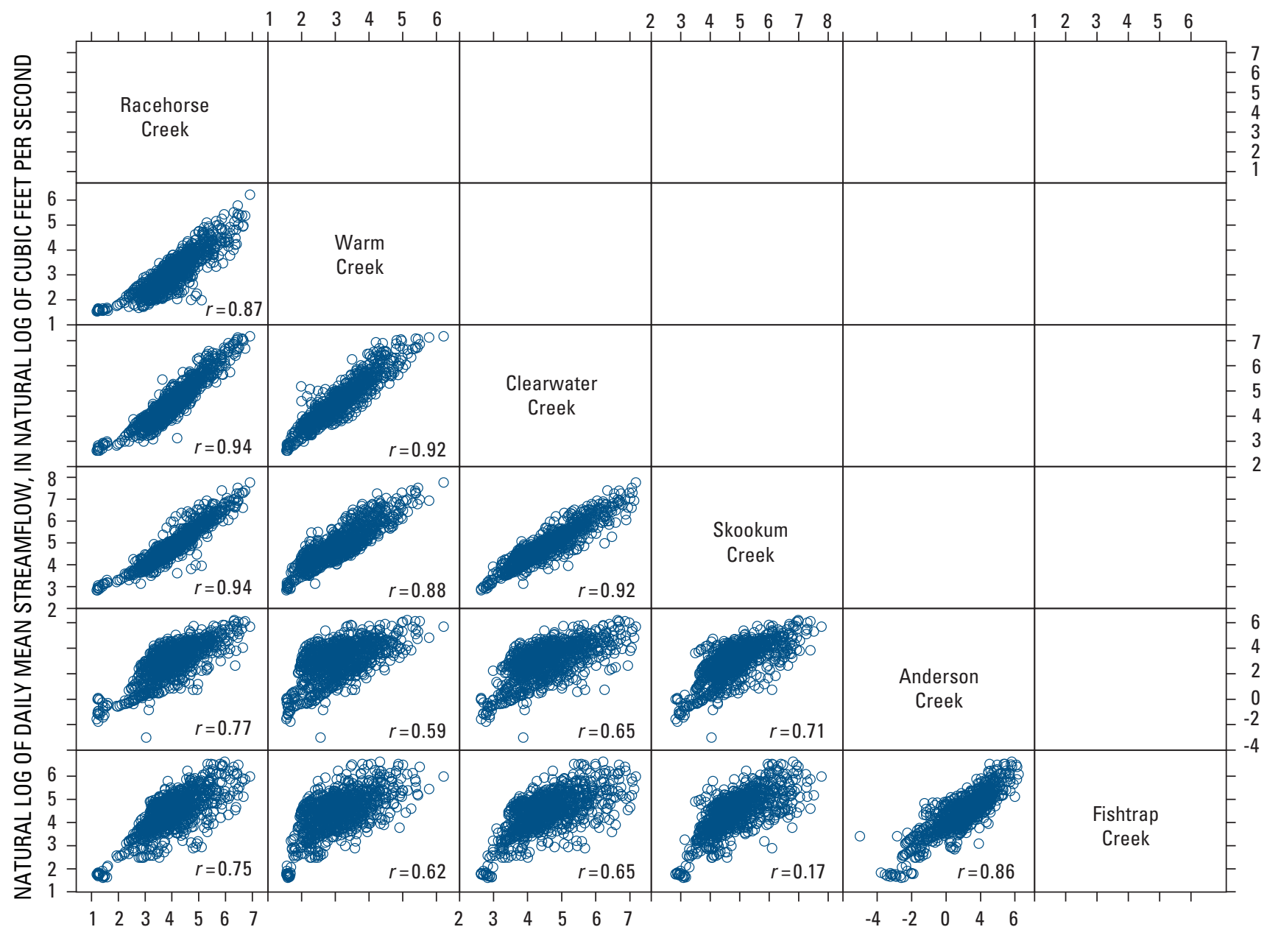

NATURAL LOG OF DAILY MEAN STREAMFLOW, IN NATURAL LOG OF CUBIC FEET PER SECOND

\section{B. Winter season (0ct. 16-Feb. 14)}

Figure 18.-Continued 


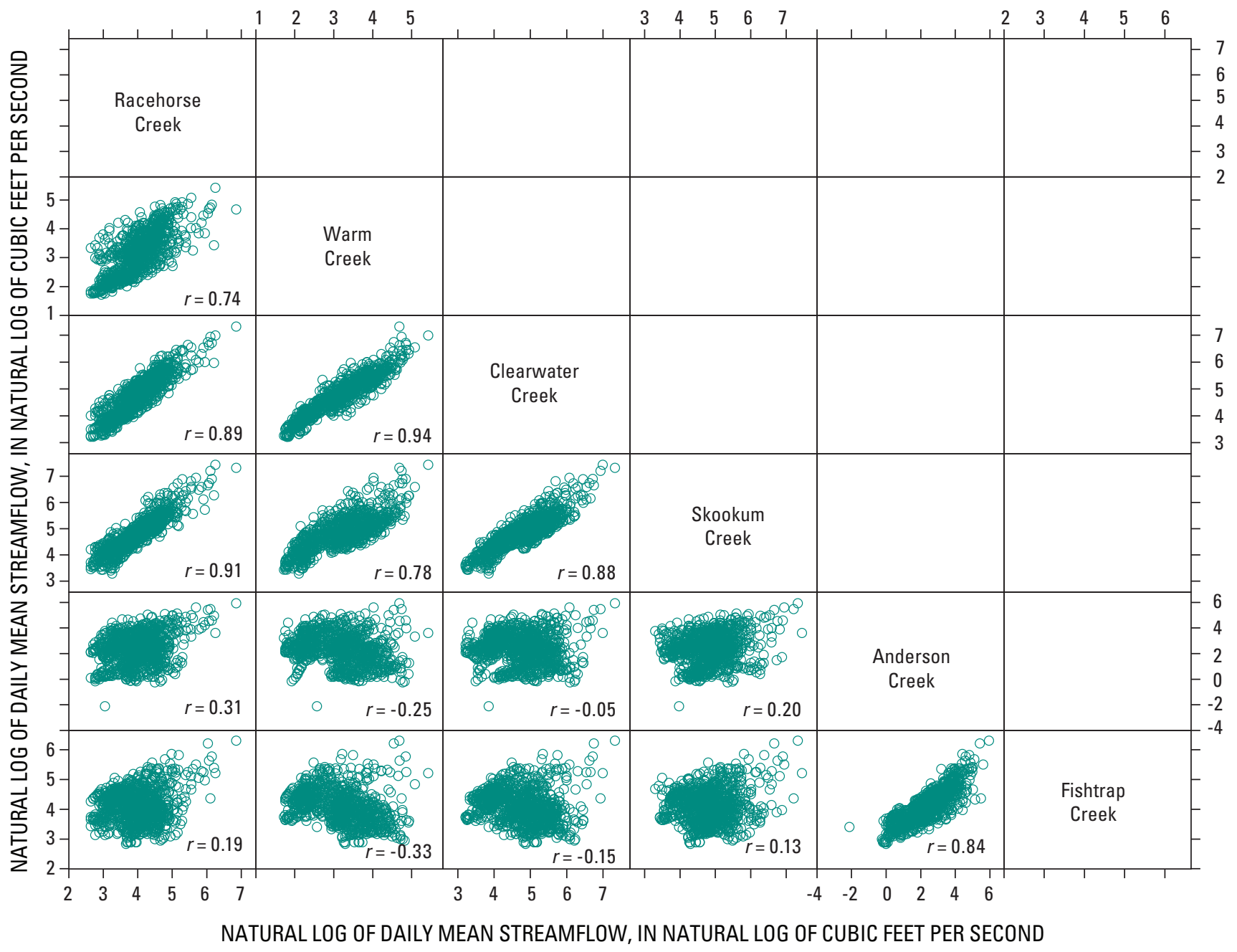

\section{Spring season (Feb. 15-June 15)}

Figure 18.-Continued 
Table 6. Summary of correlation coefficients (Pearson's $r$ ) showing patterns among the natural logs of daily mean streamflows at six gaging stations in the Racehorse, Warm, Clearwater, Skookum, Anderson, and Fishtrap Creek subbasins during summer, winter, and spring seasons, Nooksack River basin, Washington and Canada.

[Summer, defined as June 16-October 15; Winter, defined as October 16-February 14; Spring, defined as February 15-June 15. Gray shading indicates $r$ values $\geq 0.84]$

\begin{tabular}{|c|c|c|c|c|c|c|c|c|c|c|c|c|c|c|c|}
\hline \multicolumn{3}{|c|}{ Racehorse Creek } & & & & & & & & & & & & & \\
\hline 0.82 & 0.87 & 0.74 & \multicolumn{3}{|c|}{ Warm Creek } & & & & & & & & & & \\
\hline 0.94 & 0.94 & 0.89 & 0.89 & 0.92 & 0.94 & \multicolumn{3}{|c|}{ Clearwater Creek } & & & & & & & \\
\hline 0.89 & 0.94 & 0.91 & 0.90 & 0.88 & 0.78 & 0.92 & 0.92 & 0.88 & \multicolumn{3}{|c|}{ Skookum Creek } & & & & \\
\hline 0.80 & 0.77 & 0.31 & 0.54 & 0.59 & -0.25 & 0.69 & 0.65 & -0.05 & 0.63 & 0.71 & 0.20 & \multicolumn{3}{|c|}{ Anderson Creek } & \\
\hline 0.83 & 0.75 & 0.19 & 0.71 & 0.62 & -0.33 & 0.75 & 0.65 & -0.15 & 0.73 & 0.71 & 0.13 & 0.82 & 0.86 & 0.84 & Fishtrap Creek \\
\hline 离 & 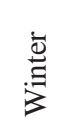 & 占 & 苛 & 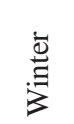 & 告 & 㽞 & 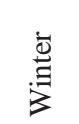 & 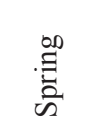 & $\begin{array}{l}\dot{\Xi} \\
\text { 亶 } \\
\text { 心 }\end{array}$ & $\underset{\xi}{\stackrel{\leftrightarrows}{J}}$ & 品 & 㔛 & 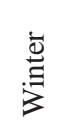 & $\stackrel{\infty}{\stackrel{D}{D}}$ & \\
\hline
\end{tabular}

Redundancy of streamflow sites in the network generally is assumed when sites correlate strongly during summer, winter, and spring. As noted previously, the redundancy findings of this method are only useful in determining which gaging stations may be eliminated from the network if the purpose of the network is to estimate daily mean streamflow in any of the six subbasins as a function of measured daily mean streamflow in at least one of the six subbasins. The redundancy findings of this method are not useful in determining which gaging stations may be eliminated from the network if the purpose of the network is to estimate regional regression equations for flow frequency statistics.

With that caveat, the patterns of correlations among the six gaging stations (table 6) indicate that the network could be reduced to either two or three stations. To avoid significant loss of information, one of the stations retained must be Fishtrap Creek (12212050) or Anderson Creek (12210900). For a reduced network of only two stations, the other station would need to be Skookum Creek (12209490) or Clearwater Creek (12207850). If either Skookum or Clearwater were not included, both Warm Creek (12207750) and Racehorse Creek (12206900) would be needed as these stations do not correlate well with each other ( $r=0.74$ and 0.82 for spring and summer season flows, respectively), and this would result in a network of three gaging stations.

\section{Variable-Space Method}

For the Nooksack River basin, drainage area (DA) and mean basin elevation (E) were the two basin attributes that explain the greatest amount of variation in regional regression equations for estimating low-flow frequency statistics at ungaged sites. One way to evaluate the redundancy in the gaging station network is to look at the proximity of stations in the variable space defined by DA and E. It is desirable to have sites span a large range in the variable space because this leads to a more robust regression. Conversely, when two or more stations are close to each other in the variable space, they share redundant information and do not add explanatory power to the regression.

As shown in figure 19, Clearwater Creek (12207850) and Skookum Creek (12209490) plot in close proximity in the DA-E variable space and, based on the variable-space method, one of these stations could be removed from the network with minor effects on regional regression equations for estimating low-flow frequency statistics. Fishtrap Creek (12212050) is in close proximity to a gaging station operated by Ecology (Bertrand Creek near mouth, 01N060) and could be removed from the network without significant loss of information, if gaging station 01N060 continues to operate.

Results from the variable-space method suggest that a network of four or five gaging stations would be optimal for future regional regression analyses of low-flow frequency statistics in the Nooksack River basin that use the basin attributes of drainage area and mean basin elevation. Such a network would contain the gaging stations-Racehorse Creek (12206900), Warm Creek (12207750), Anderson Creek (12210900), Fishtrap Creek (12212050), and Clearwater Creek (12207850) or Skookum Creek (12209490). Fishtrap Creek could be eliminated if Ecology continues the site at Bertrand Creek (01N060). 


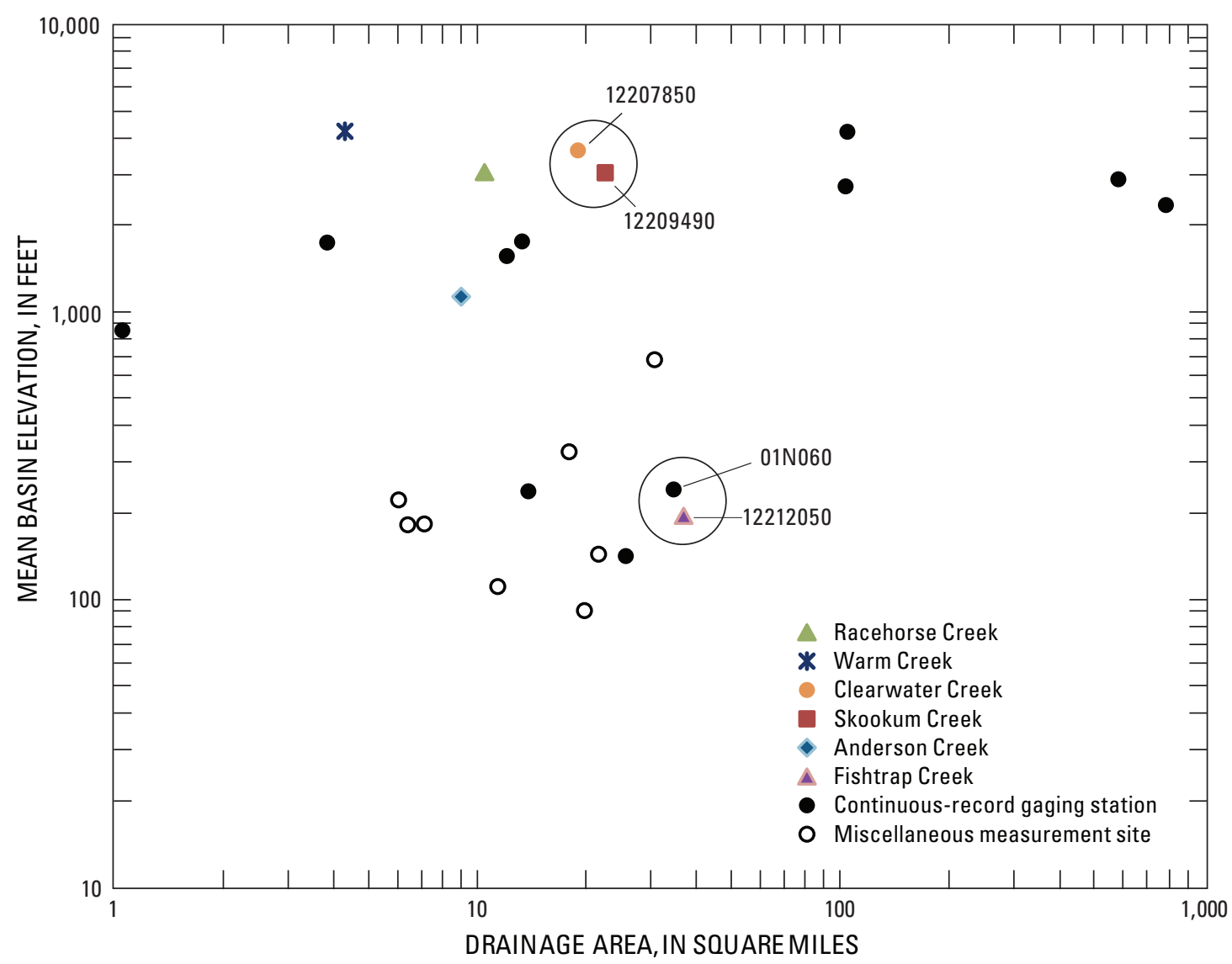

Figure 19. Drainage area and mean basin elevation for all gaging stations used in the regional regression analysis for estimating low-flow frequency statistics at ungaged sites, Nooksack River basin, Washington and Canada.

\section{Flow-Duration-Ratio Method}

Flow-duration statistics such as the Q90 (low flow) and Q50 (median flow) are defined as the streamflows that are exceeded 90 and 50 percent of the time, respectively, at a particular site. Because the Q90 or Q50 statistics generally increase with stream size, it is useful to remove the scale effect (normalize) by evaluating the ratio Q90/Q50. This results in a low-flow-duration metric that quantifies the baseflow dependence of a stream. A stream with a large Q90/Q50 ratio likely receives more baseflow from groundwater or snowmelt than a stream with a small ratio. A stream with a small Q90/ Q50 ratio may be more likely to go dry in the summer.
For the purpose of computing regional regression equations for low-flow frequency statistics, it is desirable to include streams with a range of baseflow characteristics in the analysis. As shown in figure 20, Anderson Creek (12210900) represents a flow regime with a small Q90/Q50 ratio and should remain in the network based on the low-flow-duration method. However, Fishtrap Creek (12212050) and Racehorse Creek (12206900) have similar Q90/Q50 ratios and one of these sites could be removed from the network. Similarly, Skookum Creek (12209490) and Warm Creek (12207750) also have close Q90/Q50 ratios and one of these sites could be removed from the network. Clearwater Creek (12207850), which has a Q90/Q50 ratio in between ratios of other stations used in the regression analysis, also could be removed. 


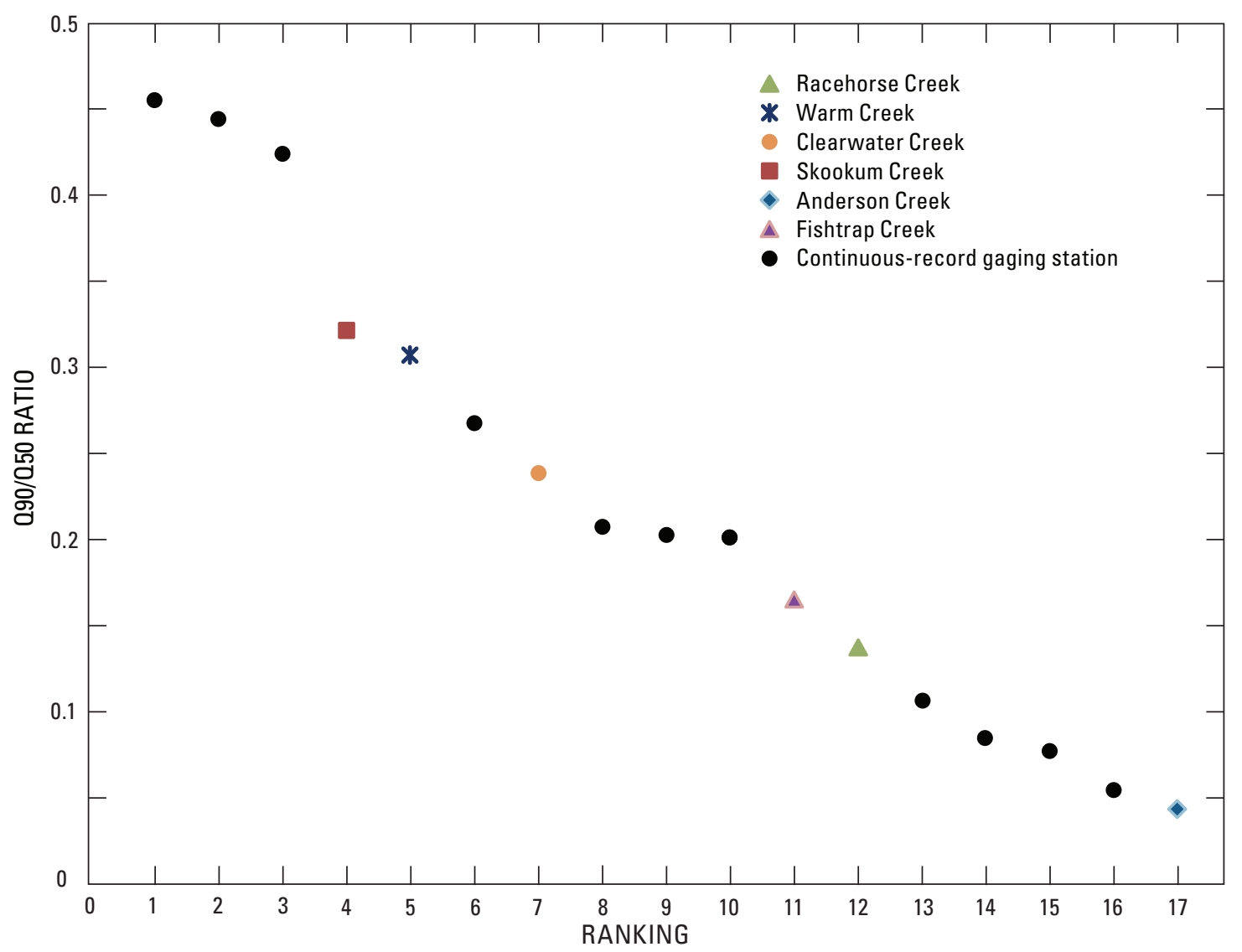

Figure 20. $090 / 050$ ratios for all sites used in the regional regression analysis for estimating low-flow frequency statistics at ungaged sites, Nooksack River basin, Washington and Canada.

Even though no regional regression equations were developed in this study for estimating high-flow frequency statistics, it is important to consider how removal of gaging stations from the network may affect the ability to develop such regressions in the future. As a result, the network was assessed for variability in high flows by considering the flow-duration statistic Q10, which represents the flow that is exceeded 10 percent of the time. Because the Q10 statistic generally increases with stream size, it is useful to remove the scale effect by normalizing and evaluating the ratio Q10/ Q50 instead. This ratio is a high-flow-duration metric that quantifies the responsiveness of a stream to precipitation. A responsive or 'flashy' stream will have a large Q10/Q50 ratio.
For the purpose of computing regional regression equations for high-flow statistics, it is desirable to include streams in the analysis representing different flow regimes, that is, streams with a large range of responses to precipitation. As shown in figure 21, Anderson Creek (12210900) represents an end-member, large Q10/Q50 ratio and should remain in the network based on the high-flow-duration method. However, Clearwater Creek (12207850), Fishtrap Creek (12212050), Racehorse Creek (12206900), Warm Creek (12207750), and Skookum Creek (12209490) have similar Q10/Q50 ratios and four of these stations could be removed from the network with likely minor effects on high-flow regional regression equations. 


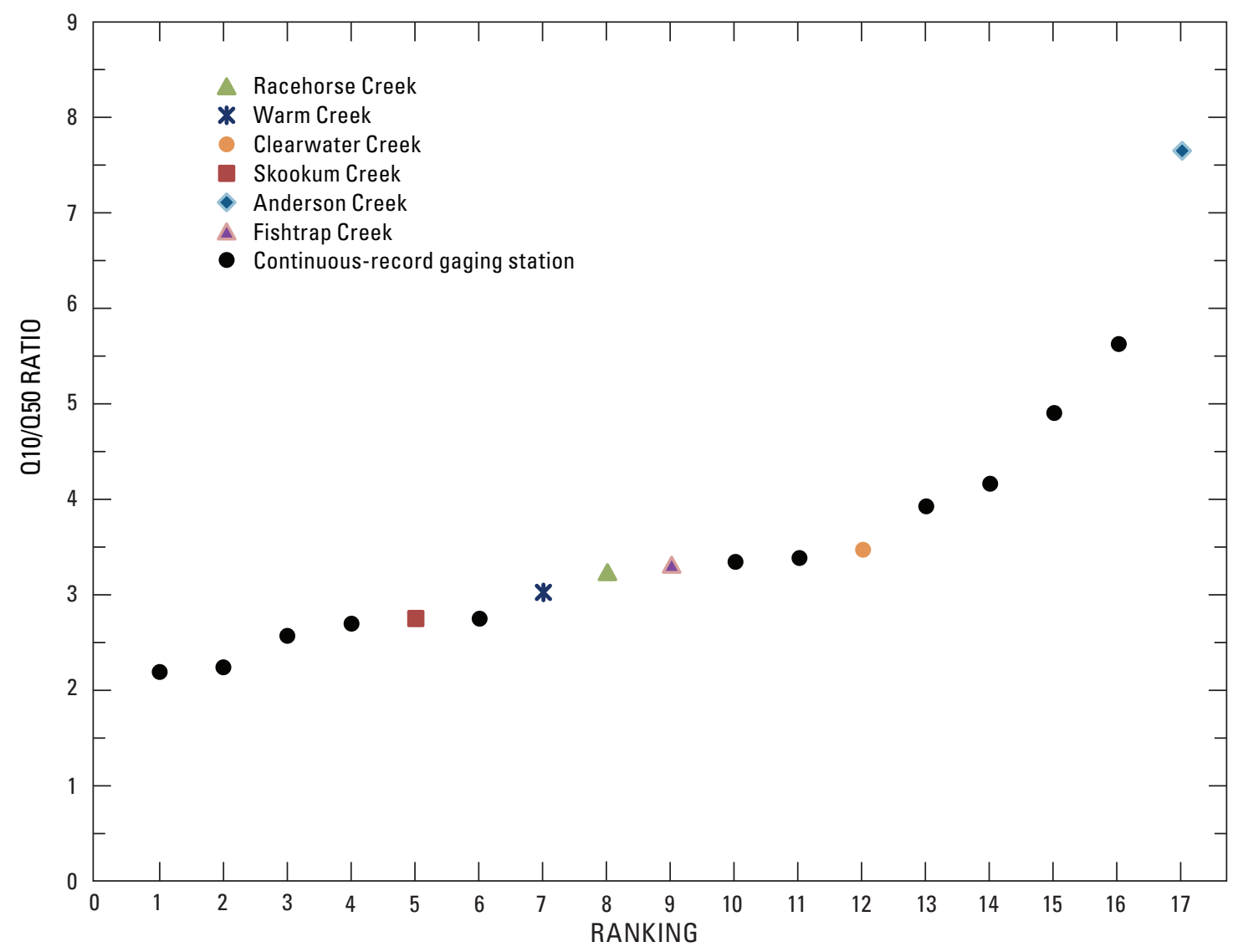

Figure 21. 010/050 ratios for all sites used in the regional regression analysis for estimating lowflow frequency statistics at ungaged sites, Nooksack River basin, Washington and Canada.

\section{Summary of Methods and Prioritization of Streamflow-Gaging Stations}

Four different methods were used to prioritize gaging stations for the purpose of optimizing the streamflow-gaging station network by reducing the redundancy of streamflow information (table 7). The first method, hydrograph comparison, was used to examine similarities in the streamflow time series for each gaging station at a daily time step during a water year and at a 15-minute time step during a baseflow recession period. The second method, the dailyvalue-correlation method, was used to determine which of the gaging stations collect redundant information if the purpose of the network is to estimate daily mean streamflows in the six subbasins. The variable-space method was used to determine which gaging stations are important for developing low-flow regional regression equations using basin attributes of drainage area and mean basin elevation. The flow-duration-ratio method provided metrics for low flows and high flows (Q90/Q50 and Q10/Q50, respectively), and was used to evaluate the variability of hydrologic response in the network as well as the importance of sites for developing regression equations for estimating low- and high-flow frequency statistics. Each of the methods could be used to suggest a different optimal network configuration that would benefit future data analyses or needs. Thus, it is difficult to develop a quantitative measure to combine these results and create one prioritized list of gaging stations. This also means that removing any of the gaging stations from the network will result in some loss of information and, for example, reduce the accuracy of regional regression equations or estimates of daily mean flow in the six subbasins of the Nooksack River basin. However, it is possible to make a qualitative prioritization of the six streamflowgaging stations. 
Table 7. Summary of results by method for determining optimal combinations of streamflow-gaging stations to retain in six subbasins, Nooksack River basin, Washington and Canada.

\begin{tabular}{|c|c|c|}
\hline Method & Purpose & Results \\
\hline Hydrograph comparison & $\begin{array}{l}\text { Identifying redundancy in } \\
\text { timing and magnitude of } \\
\text { peak flows and baseflow- } \\
\text { recession characteristics }\end{array}$ & $\begin{array}{l}4 \text { stations (baseflow priority): Anderson Creek, Fishtrap Creek, and Skookum or } \\
\text { Warm Creek, and Clearwater or Racehorse Creek }\end{array}$ \\
\hline \multirow[t]{3}{*}{ Daily-value correlation } & \multirow{3}{*}{$\begin{array}{l}\text { Identifying redundancy } \\
\text { in concurrent daily } \\
\text { streamflow }\end{array}$} & Network could be reduced to 2 or 3 stations \\
\hline & & 2 stations: Fishtrap or Anderson Creek, and Skookum or Clearwater Creek \\
\hline & & 3 stations: Warm Creek, Racehorse Creek, and Fishtrap or Anderson Creek \\
\hline \multirow{2}{*}{ Variable space } & \multirow{2}{*}{$\begin{array}{l}\text { Identifying redundancy in } \\
\text { the variable space defined } \\
\text { by basin attributes used } \\
\text { in regional regression } \\
\text { analysis }\end{array}$} & $\begin{array}{l}4 \text { stations: Anderson Creek, Warm Creek, Racehorse Creek, and Skookum or } \\
\text { Clearwater Creek }\end{array}$ \\
\hline & & $\begin{array}{l}5 \text { stations: Anderson Creek, Warm Creek, Fishtrap Creek, Racehorse Creek and } \\
\text { Skookum or Clearwater Creek }\end{array}$ \\
\hline \multirow[t]{2}{*}{ Flow-duration ratio } & \multirow{2}{*}{$\begin{array}{l}\text { Identifying redundancy in } \\
\text { the relative frequency } \\
\text { of extreme flows }\end{array}$} & $\begin{array}{l}\text { Network could be reduced to } 2 \text { or } 3 \text { stations, depending on low-flow or high- } \\
\text { flow priority }\end{array}$ \\
\hline & & $\begin{array}{l}2 \text { stations (high-flow priority): Anderson Creek, and Warm, Skookum, } \\
\text { Clearwater, Fishtrap, or Racehorse Creek }\end{array}$ \\
\hline
\end{tabular}

The six streamflow-gaging stations were ranked in order of priority using a qualitative summary of the four methods and, when applicable, other factors relating to individual subbasins and gaging stations previously described (table 8). The rationale for the priority rankings is discussed below for each gaging station.

- Skookum Creek shares the highest rank because, as demonstrated by the daily-value correlation method, streamflow data from this gaging station would likely provide a reasonable estimate of streamflow at other mountain streams. However, Skookum Creek would likely not provide the best estimate of streamflow for lowland streams. Skookum Creek shares unique variable space (important for regional regression analysis) with Clearwater Creek, which was ranked sixth. Streamflow data from the Skookum Creek gaging station is used by the National Weather Service for calibrating a hydrologic model for the South Fork Nooksack River.
- Anderson Creek shares the highest rank because it represents a natural lowland stream, occupies unique drainage area-mean basin elevation variable space, and has flow-duration ratios for high and low flow that make it unique in the basin. Anderson Creek also has periods of zero flow during the summer, making it valuable for future regional logistic regression studies.

- Warm Creek is ranked third because it provides unique information in the daily-value correlation and variable-space methods. Because of its high elevation and thus increased snow accumulation, streamflow in the Warm Creek subbasin has a larger component of snowmelt per unit area than other sites and melting starts later in the season. The high elevation combined with a small drainage area makes this site unique and it fills an important part of the variable space for regression equations. 
Table 8. Prioritized list of streamflow-gaging stations to retain in six subbasins of the Nooksack River basin, Washington and Canada. [WA, Washington]

\begin{tabular}{llccc}
\hline Station No. & \multicolumn{1}{c}{ Station name } & $\begin{array}{c}\text { Latitude } \\
\text { (decimal degrees) }\end{array}$ & $\begin{array}{c}\text { Longitude } \\
\text { (decimal degrees) }\end{array}$ & $\begin{array}{c}\text { Priority ranking for } \\
\text { retaining station in } \\
\text { streamflow-gaging } \\
\text { station network }\end{array}$ \\
\hline 12209490 & Skookum Creek above diversion, near Wickersham, WA & 48.67150163 & -122.13959998 & 1 \\
12210900 & Anderson Creek at Smith Road, near Goshen, WA & 48.83261414 & -122.33905016 & 1 \\
12207750 & Warm Creek near Welcome, WA & 48.76733993 & -121.96459472 & 3 \\
12212050 & Fishtrap Creek at Front Street, at Lynden, WA & 48.93872574 & -122.47905316 & 4 \\
12206900 & Racehorse Creek at North Fork Road, near Kendall, WA & 48.88484196 & -122.13320746 & 5 \\
12207850 & Clearwater Creek near Welcome, WA & 48.78845101 & -122.02292921 & 6 \\
\hline
\end{tabular}

- Fishtrap Creek is ranked fourth because it represents a lowland stream that is affected by agricultural activities and urbanization (to a greater degree than Anderson Creek) and has baseflow recession characteristics that are different from the other gaging stations. This station represents an important index station that was consistently selected to estimate streamflow characteristics at most of the miscellaneous measurement sites in the basin based on geographic proximity and similar variable space (drainage area and mean basin elevation). The priority ranking of this gaging station could be lowered if Ecology continues to operate the gaging station on Bertrand Creek (01N060) and EC continues to operate the gaging station upstream on Fishtrap Creek (0MH153).

- Racehorse Creek is ranked fifth because although it occupies unique variable space, it is similar to other stations for most of the methods used. The subbasin measured by the gaging station recently experienced profound channel changes that could make it difficult to maintain an accurate stage-discharge relation at this station for the foreseeable future.

- Clearwater Creek is ranked sixth because it is similar to Skookum Creek in daily-value correlation and variable space. The creek is in close proximity to Warm Creek and has baseflow recession characteristics similar to Racehorse Creek. The streamflow record for Clearwater Creek also is shorter than for the other stations and is missing data from October 2006 to July 2008 ( 21 months) due to a flood that damaged the gaging station.

Overall, it appears that a minimal network should contain two gaging stations: Skookum Creek, which is a mountain-stream station, and Anderson Creek, which is a lowland-stream station. The optimal streamflow-gaging station network should contain five stations, representing (1) tributaries for each fork of the Nooksack River, (2) mountainstream and lowland-stream subbasins, and (3) different baseflow recession characteristics. Clearwater Creek could be removed because it consistently appears as a redundant site among all methods used. Of all the methods used to analyze the network, the daily-value-correlation and variablespace methods are the most important to consider, as these relate directly to further quantitative uses of the data, such as estimating missing streamflow at gaged sites and developing regional regression equations to estimate streamflowfrequency statistics at ungaged sites. The priority of one of these methods over the other depends on the purpose of the streamflow-gaging station network.

\section{Summary}

The Nooksack River, including its tributaries and ecosystems, faces increasing pressures for water demand, flood protection, and riparian land use. The streamflow-gaging station network in the Nooksack River basin is an important asset in managing the basin's water resources as it provides the necessary data for water managers, regulators, and scientists to monitor water availability. The streamflow-gaging station network in the basin consists of 17 streamflow-gaging stations and 8 miscellaneous measurement sites operated by Federal, State, and Canadian government agencies. The Lummi Nation, an indigenous tribe of Native Americans, has funded operation of six of the streamflow-gaging stations operated by the USGS for the past 10 years, and has requested that the USGS provide an analysis of the streamflow data.

The study documented in this report assembled streamflow data from 12 continuous-record gaging stations (CG), 5 short-term continuous-record gaging stations 
(STCG), and 8 miscellaneous measurement sites in or near the Nooksack River basin, and determined low-flow frequency statistics for $1,3,7,15,30$, and 60 consecutive-day low flows with recurrence intervals of 2 and 10 years. Streamflow-gaging stations with 7 or more years of continuous streamflow record were considered CG stations; stations with less than 7 years of record were considered STCG stations. Miscellaneous measurement sites with 10 or more measurements of streamflow during baseflow periods were used in the analysis of low-flow frequency statistics. Whereas low-flow frequency statistics were computed directly from the streamflow record at $\mathrm{CG}$ stations, the Maintenance of Variance Extension version 1 (MOVE.1) statistical method was first used to extend the record at STCG stations to 7 years before low-flow frequency statistics were computed. At miscellaneous measurement sites, MOVE.1 was used to estimate low-flow frequency statistics using similar statistics from nearby or hydrologically similar CG stations.

Because the Lummi Nation is interested in estimating streamflow at locations in the Nooksack River basin where streamflow-gaging stations or miscellaneous measurement sites do not exist, regional regression equations were developed for estimating the low-flow frequency statistics at ungaged sites. Equations were developed for estimating low-flow frequency statistics for the $1,3,7,15,30$, and 60 consecutive-day low flows with recurrence intervals of 2 and 10 years. The equations were developed from the streamflow statistics previously determined at $12 \mathrm{CG}$ and 5 STCG stations, 8 miscellaneous measurement sites, and the basin characteristics determined at each site. A total of 26 basin characteristics, such as drainage area, mean annual precipitation, and percentage of area with surficial geology classified as bedrock were examined for use as explanatory variables in the regression equations. The stepwise regression analysis and tests for multicollinearity were used iteratively to select the final basin characteristics, drainage area and mean basin elevation, as explanatory variables in the regression equations. The USGS software program WREG (version 1.0) was used to develop weighted-least-squares (WLS) regression equations for estimating low-flow frequency statistics at ungaged sites in the Nooksack River basin. The WLS method used gave more weight in the regression models to sites with longer periods of record and thus presumably more accurate streamflow statistics. Performance metrics such as the coefficient of determination $\left(R^{2}\right)$ and root-mean-squared error (RMSE) expressed as a percentage were calculated for each of the regression equations and ranged from 0.79 to 0.93 and 77 to 560 percent, respectively.
In addition to developing regional regression equations for low-flow frequency statistics, the Lummi Nation requested that the USGS determine whether some of the six streamflow-gaging stations were collecting redundant streamflow information and if some of the gaging stations could be removed from the network without significant loss of information. Four methods were used for considering data redundancy: hydrograph comparison, daily-value correlation, variable space, and flow-duration ratios. The hydrographcomparison method found similarities and differences between gaging stations in the streamflow record during a water year at a daily time step and during the baseflow recession period at a 15-minute time step. The daily-value-correlation method identified which of the gaging stations collect redundant information and is a useful method if the purpose of the network is to estimate daily mean streamflows in the six subbasins. The variable-space method identified which gaging stations occupy unique variable space and is important for determining the relative importance of gaging stations for developing regional regression equations. The flow-durationratio method provided metrics for low flows and high flows (Q90/Q50 and Q10/Q50, respectively), and was used to evaluate the variability of hydrologic response in the network. The results from each method should be considered along with the intended long-term use of the data-collection network. In evaluating the six gaging stations, the subbasins for each of the gaging stations also were characterized based on land use, surficial geology, and streamflow characteristics. Although each of the methods could be used to suggest a different optimal network configuration, a qualitative prioritization of the six gaging stations was made from most to least important as follows: Skookum Creek (12209490), Anderson Creek (12210900), Warm Creek (12207750), Fishtrap Creek (12212050), Racehorse Creek (12206900), and Clearwater Creek (12207850). The optimum streamflow-gaging station network would contain all gaging stations except Clearwater Creek, and the minimum network would include Skookum Creek and Anderson Creek. The optimal network configuration depends largely on the expected future use of the streamflow-gaging station network.

\section{Acknowledgments}

The authors gratefully acknowledge the dedication of the hydrologic technicians at the USGS Sedro Wooley Field Office in collecting high-quality streamflow data and maintaining the streamflow-gaging stations in the Nooksack River basin, without which this study would not have been possible. 


\section{References Cited}

Cox, S.E., Simonds, F.W., Doremus, Llyn, Huffman, R.L., and Defawe, R.M., 2005, Groundwater/surface water interactions and quality of discharging groundwater in streams of the lower Nooksack River Basin, Whatcom County, Washington: U.S. Geological Survey Scientific Investigations Report 2005-5255, 46 p.

Cummans, J.E., 1976, Low-flow characteristics of streams on the Kitsap Peninsula and selected adjacent islands, Washington: U.S. Geological Survey Open-File Report 76-704, 44 p.

Dragovich, J.D., Dunn, A., Parkinson, K.T., Kahle, S.C., and Pringle, P.T., 1997b, Quaternary stratigraphy and crosssections, Nooksack, Columbia, and Saar Creek Valleys, Kendall and Deming 7.5-minute quadrangles, Western Whatcom County, Washington: Washington Division of Geology and Earth Resources Open-File Report 97-4, 13 p.

Easterbrook, D.J., Kovanen, D.J., and Slaymaker, O., 2007, New developments in late Pleistocene and Holocene glaciations and volcanism in the Fraser Lowland and North Cascades, Washington, in Stelling P., and Tucker, D.S., eds., Floods, Faults and Fire: Geological Field Trips in Washington State and Southwest British Columbia: Geological Society of America Field Guide 9, p. 31-56.

Eng, K., and Milly, P.C.D., 2007, Relating low-flow characteristics to the base flow recession time constant at partial record stream gauges: Water Resources Research, v. 43, 8 p.

Funkouser, J.E., Eng, K., and Moix, M.W., 2008, Lowflow characteristics and regionalization of low-flow characteristics for selected streams in Arkansas: U.S. Geological Survey Scientific Investigations Report 2008-5065, 170 p.

Haushild, W.L., and LaFrance, D.E., 1977, Low-flow characteristics of streams on the Olympic Peninsula, Washington: U.S. Geological Survey Open-File Report 77-812, 25 p.

Hidaka, F.T., 1973, Low-flow characteristics of streams in the Puget Sound Region, Washington: U.S. Geological Survey Open-File Report 72-163, 55 p., 1 map sheet.

Hirsch, R.M., 1982, A comparison of four streamflow record extension techniques: Water Resources Research, v. 18, no. 4., p. 1081-1088.

Hortness, J.E., 2006, Estimating low-flow frequency statistics for unregulated streams in Idaho: U.S. Geological Survey Scientific Investigations Report 2006-5035, 31 p.

Jones, M.A., 1999, Geologic framework of the Puget Sound aquifer system, Washington and British Columbia: U.S. Geological Survey Professional Paper 1424-C, 31 p.
Linneman, S., Pittman, P., and Vaugeois, L., 2007, Lively Landscapes: Major Holocene Geomorphic Events in the Nooksack -Sumas Valley, in Stelling P., and Tucker, D.S., eds., Floods, Faults and Fire: Geological Field Trips in Washington State and Southwest British Columbia: Geological Society of America Field Guide 9, p. 99-119.

Multi-Resolution Land Characteristics Consortium (MRLC), 2001, National Land Cover Database 2001, accessed March 2009 at URL: http://www.mrlc.gov/index.php

National Oceanic and Atmospheric Administration, 2007, Climatological Data, Annual Summary, Washington, 2007 (Bellingham and Clearbrook stations): National Climatic Data Center, Asheville, NC, v. 111, no. 13, 30 p.

PRISM Climate Group, 1998, accessed March 2009 at URL http://www.prism.oregonstate.edu/index.phtml

Ries, K.G., and Friesz, P.J., 2000, Methods for estimating lowflow statistics for Massachusetts streams: Water-Resources Investigation Report 2000-4135, $81 \mathrm{p}$.

Riggs, H.C., 1972, Low-flow investigations: U.S. Geological Survey Techniques of Water-Resource Investigations, book 4, chap. B1, 18 p.

Risley, J., Stonewall, A., and Haluska, T., 2008, Estimating flow-duration and low-flow frequency statistics for unregulated streams in Oregon: U.S. Geological Survey Scientific Investigations Report 2008-5126, 22 p.

TIBCO Software Inc., 2008, Spotfire S+ Version 8.1 for Windows.

U.S. Census Bureau, 2000, United States Census 2000, accessed April 2009 at URL http://www.census.gov/main/ www/cen2000.html

U.S. Geological Survey, 2008, Water-Data Report 2008: USGS 12213100 Nooksack River at Ferndale, Washington, accessed May 2009, at URL http://wdr.water.usgs.gov/ wy2008/pdfs/12213100.2008.pdf

Vaccaro, J.J., Hansen, A.J., and Jones, M.A., 1998, Hydrogeologic framework of the Puget Sound aquifer system, Washington and British Columbia: U.S. Geological Survey Professional Paper 1424-D, 77 p.

Washington Department of Fish and Wildlife, 2002, Salmonid Stock Inventory, accessed May 2009 at URL http://wdfw. wa.gov/fish/sasi/

Washington State Department of Ecology, 1985, Nooksack water resources inventory area: Instream resources protection program including administrative rules (Water Resource Inventory Area 1), State Water Program, W.W.I.R.P.P. series, no. 11, Washington State Department of Ecology, Olympia, WA., 193 p. 
This page intentionally left blank. 


\section{Appendix A. Regression Equations for Estimating Daily Mean Streamflow at Six Gaging Stations in the Nooksack River Basin}

As part of the daily-value correlation method, regression analyses were conducted in natural log space using Linear Organic Correlation to determine redundancy in streamflow information among six streamflow-gaging stations in the Nooksack River basin. By transforming the resulting regression equations from natural $\log$ space back into standard space, a set of equations resulted (table A1) that can be used to estimate daily mean streamflow at any one of the six stations as a function of daily mean streamflow at another of the six stations. The ability to estimate daily mean streamflow may be useful for filling in periods of missing record at any of the six gages, or extending the record at gages that may be discontinued. When estimating daily mean streamflow using regression equations, the equation for the appropriate season and with the largest correlation coefficient should be selected (table 6).
Table A1. Regression equations for estimating daily mean streamflow at six gaging stations, Nooksack River basin, Washington and Canada.

[All units of streamflow are in cubic feet per second. Equations highlighted in gray have $r$ values $\geq 0.84$; A, is daily mean streamflow for Racehorse Creek at USGS gaging station 12206900. B, is daily mean streamflow for Warm Creek at USGS gaging station 12207750; C, is daily mean streamflow for Clearwater Creek at USGS gaging station 12207850 . D, is daily mean streamflow for Skookum Creek at USGS gaging station 12209490; E, is daily mean streamflow for Anderson Creek at USGS gaging station 12210900; F, is daily mean streamflow for Fishtrap Creek at USGS gaging station 12212050]

\begin{tabular}{|c|c|c|}
\hline $\begin{array}{c}\text { Summer } \\
\text { (June 16-Oct. 15) }\end{array}$ & $\begin{array}{c}\text { Winter } \\
\text { (Oct. 16-Feb. 14) }\end{array}$ & $\begin{array}{c}\text { Spring } \\
\text { (Feb. 15-June 15) }\end{array}$ \\
\hline $\mathrm{A}=0.468 \times \mathrm{B}^{1.2}$ & $\mathrm{~A}=1.393 \times \mathrm{B}^{1.2}$ & $\mathrm{~A}=3.56 \times \mathrm{B}^{0.866}$ \\
\hline $\mathrm{A}=0.192 \times \mathrm{C}^{1.12}$ & $\mathrm{~A}=0.397 \times \mathrm{C}^{1.09}$ & $\mathrm{~A}=0.783 \times \mathrm{C}^{0.892}$ \\
\hline $\mathrm{A}=0.035 \times \mathrm{D}^{1.46}$ & $\mathrm{~A}=0.256 \times \mathrm{D}^{1.11}$ & $\mathrm{~A}=0.415 \times \mathrm{D}^{1.01}$ \\
\hline $\mathrm{A}=17.4 \times \mathrm{E}^{0.769}$ & $\mathrm{~A}=7.78 \times \mathrm{E}^{0.662}$ & $\mathrm{~A}=14.7 \times \mathrm{E}^{0.544}$ \\
\hline $\mathrm{A}=0.252 \times \mathrm{F}^{1.57}$ & $\mathrm{~A}=0.430 \times \mathrm{F}^{1.1}$ & $\mathrm{~A}=0.446 \times \mathrm{F}^{1.16}$ \\
\hline $\mathrm{B}=1.89 \times \mathrm{A}^{0.836}$ & $\mathrm{~B}=0.758 \times \mathrm{A}^{0.835}$ & $\mathrm{~B}=0.231 \times \mathrm{A}^{1.15}$ \\
\hline $\mathrm{B}=0.474 \times \mathrm{C}^{0.938}$ & $\mathrm{~B}=0.350 \times \mathrm{C}^{0.907}$ & $\mathrm{~B}=0.174 \times \mathrm{C}^{1.03}$ \\
\hline $\mathrm{B}=0.115 \times \mathrm{D}^{1.22}$ & $\mathrm{~B}=0.243 \times \mathrm{D}^{0.924}$ & $\mathrm{~B}=0.084 \times \mathrm{D}^{1.16}$ \\
\hline $\mathrm{B}=20.6 \times \mathrm{E}^{0.643}$ & $\mathrm{~B}=4.21 \times \mathrm{E}^{0.553}$ & $\mathrm{~B}=101 \times \mathrm{E}^{-0.628}$ \\
\hline $\mathrm{B}=0.596 \times \mathrm{F}^{1.31}$ & $\mathrm{~B}=0.375 \times \mathrm{F}^{0.916}$ & $\mathrm{~B}=5,710 \times \mathrm{F}^{-1.34}$ \\
\hline $\mathrm{C}=4.36 \times \mathrm{A}^{0.892}$ & $\mathrm{C}=2.34 \times \mathrm{A}^{0.921}$ & $\mathrm{C}=1.32 \times \mathrm{A}^{1.12}$ \\
\hline $\mathrm{C}=2.22 \times \mathrm{B}^{1.07}$ & $\mathrm{C}=3.18 \times \mathrm{B}^{1.1}$ & $\mathrm{C}=5.47 \times \mathrm{B}^{0.971}$ \\
\hline $\mathrm{C}=0.220 \times \mathrm{D}^{1.3}$ & $\mathrm{C}=0.669 \times \mathrm{D}^{1.02}$ & $\mathrm{C}=0.491 \times \mathrm{D}^{1.13}$ \\
\hline $\mathrm{C}=55.7 \times \mathrm{E}^{0.686}$ & $\mathrm{C}=15.5 \times \mathrm{E}^{0.61}$ & $\mathrm{C}=486 \times \mathrm{E}^{-0.61}$ \\
\hline $\mathrm{C}=1.28 \times \mathrm{F}^{1.4}$ & $\mathrm{C}=1.08 \times \mathrm{F}^{1.01}$ & $\mathrm{C}=24,300 \times \mathrm{F}^{-1.31}$ \\
\hline $\mathrm{D}=9.89 \times \mathrm{A}^{0.684}$ & $\mathrm{D}=3.42 \times \mathrm{A}^{0.904}$ & $\mathrm{D}=2.40 \times \mathrm{A}^{0.993}$ \\
\hline $\mathrm{D}=5.88 \times \mathrm{B}^{0.818}$ & $\mathrm{D}=4.61 \times \mathrm{B}^{1.08}$ & $\mathrm{D}=8.46 \times \mathrm{B}^{0.86}$ \\
\hline $\mathrm{D}=3.20 \times \mathrm{C}^{0.767}$ & $\mathrm{D}=1.48 \times \mathrm{C}^{0.981}$ & $\mathrm{D}=1.88 \times \mathrm{C}^{0.886}$ \\
\hline $\mathrm{D}=69.9 \times \mathrm{E}^{0.526}$ & $\mathrm{D}=21.9 \times \mathrm{E}^{0.598}$ & $\mathrm{D}=34.5 \times \mathrm{E}^{0.54}$ \\
\hline $\mathrm{D}=3.85 \times \mathrm{F}^{1.07}$ & $\mathrm{D}=1.60 \times \mathrm{F}^{0.991}$ & $\mathrm{D}=1.08 \times \mathrm{F}^{1.16}$ \\
\hline $\mathrm{E}=0.024 \times \mathrm{A}^{1.3}$ & $\mathrm{E}=0.045 \times \mathrm{A}^{1.51}$ & $\mathrm{E}=0.007 \times \mathrm{A}^{1.84}$ \\
\hline $\mathrm{E}=0.009 \times \mathrm{B}^{1.55}$ & $\mathrm{E}=0.074 \times \mathrm{B}^{1.81}$ & $\mathrm{E}=1,570 \times \mathrm{B}^{-1.59}$ \\
\hline $\mathrm{E}=0.003 \times \mathrm{C}^{1.46}$ & $\mathrm{E}=0.011 \times \mathrm{C}^{1.64}$ & $\mathrm{E}=25,300 \times \mathrm{C}^{-1.64}$ \\
\hline $\mathrm{E}=0.0003 \times \mathrm{D}^{1.9}$ & $\mathrm{E}=0.006 \times \mathrm{D}^{1.67}$ & $\mathrm{E}=0.001 \times \mathrm{D}^{1.85}$ \\
\hline $\mathrm{E}=0.004 \times \mathrm{F}^{2.04}$ & $\mathrm{E}=0.013 \times \mathrm{F}^{1.66}$ & $\mathrm{E}=0.002 \times \mathrm{F}^{2.14}$ \\
\hline $\mathrm{F}=2.41 \times \mathrm{A}^{0.638}$ & $\mathrm{~F}=2.16 \times \mathrm{A}^{0.912}$ & $\mathrm{~F}=2.00 \times \mathrm{A}^{0.859}$ \\
\hline $\mathrm{F}=1.48 \times \mathrm{B}^{0.763}$ & $\mathrm{~F}=2.92 \times \mathrm{B}^{1.09}$ & $\mathrm{~F}=626 \times \mathrm{B}^{-0.744}$ \\
\hline $\mathrm{F}=0.840 \times \mathrm{C}^{0.716}$ & $\mathrm{~F}=0.929 \times \mathrm{C}^{0.99}$ & $\mathrm{~F}=2,300 \times \mathrm{C}^{-0.766}$ \\
\hline $\mathrm{F}=0.284 \times \mathrm{D}^{0.933}$ & $\mathrm{~F}=0.624 \times \mathrm{D}^{1.01}$ & $\mathrm{~F}=0.938 \times \mathrm{D}^{0.866}$ \\
\hline $\mathrm{F}=14.9 \times \mathrm{E}^{0.491}$ & $F=14.0 \times E^{0.604}$ & $\mathrm{~F}=20.1 \times \mathrm{E}^{0.468}$ \\
\hline
\end{tabular}


This page intentionally left blank. 
Publishing support provided by the U.S. Geological Survey

Publishing Network, Tacoma Publishing Service Center

For more information concerning the research in this report, contact the Director, Washington Water Science Center

U.S. Geological Survey

934 Broadway — Suite 300

Tacoma, Washington 98402

http://wa.water.usgs.gov 
曼

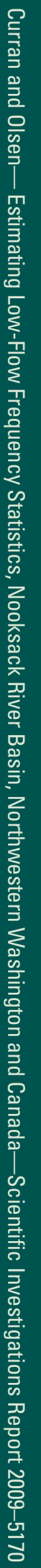

